\title{
Agriculture Credit in Developing Economies: A Review of Relevant Literature
}

\author{
Priyanka Yadav $^{1} \&$ Anil K. Sharma ${ }^{2}$ \\ ${ }^{1}$ Research Scholar, Department of Management Studies, Indian Institute of Technology, Roorkee, India \\ ${ }^{2}$ Associate Professor, Department of Management Studies, Indian Institute of Technology, Roorkee, India \\ Correspondence: Priyanka Yadav, Research Scholar, Department of Management studies, Indian Institute of \\ Technology, Roorkee 247667, India. E-mail: priyanka_cfa2011@yahoo.in
}

Received: September 21, 2015

Accepted: October 16, 2015

Online Published: November 25, 2015

doi:10.5539/ijef.v7n12p219

URL: http://dx.doi.org/10.5539/ijef.v7n12p219

\begin{abstract}
This paper aims to present a comprehensive review of 110 studies on agriculture credit in developing countries during 1995 to 2015. The literature has been classified and presented on the basis of time period, country of study, methodology used, issues covered, and sources of study. Agriculture credit has gained interest of policy makers and researchers in developing economies in recent years with raising concerns of issues like food security and rising population. However, the situation of small and marginal farmers is still vulnerable and they lack timely and adequate access to institutional sources of finance. Non-institutional sources of credit are still dominant in rural credit markets; while the role of micro-finance appears dubious. This study will prove helpful for policy makers and future researchers who wish to study diverse issues in rural finance in general and agriculture credit in particular.
\end{abstract}

Keywords: agriculture credit, repayment issues, credit rationing, agricultural productivity, development

\section{Introduction}

Agriculture is an essential economic sector of all world economies- be it developed, developing or under-developed, but it is the most important sector of a developing economy in terms of output and employment generation as compared to other sectors. (Soubbotina \& Sheram, 2000). Agriculture plays a predominant role in economic development of developing economies. Developing economy is one such economy which is characterized by the presence of both rural and urban sectors and is heavily dependent on agriculture (Mylott, 2009; Fan et al., 2005). The agriculture sector not only fosters the growth process of these economies but also provides food to their ever-growing population and provides employment to larger parts of their workforce. It is the backbone of an economy which supports rest other sectors. While the manufacturing sector needs direct input from agriculture in form of raw material, service sector is indirectly dependent on agriculture. Agriculture sector is crucial for both rural and urban sectors of an economy as it generates employment opportunities in the former and provides food and raw material to the latter. Besides it crucial importance in the overall development process, farmers in developing countries are to a large extent constrained by credit. The non-availability of adequate credit when needed negatively impacts the farm output (Guirkinger \& Boucher, 2008; Feder et al., 1990). The exclusion of masses from basic services of a financial system leads to significant loss in gross domestic product (GDP) of a country (Chattopadhyay, 2011). As the agriculture sector in such economies is dominated by small and marginal farmers, governments play an active role and initiate several policy measures time-to-time to improve situation of such farmers (Khandker \& Koolwal, 2015). Still the majority of these farmers lack the timely access to institutional credit in adequate amounts needed in the production process.

Therefore, it becomes necessary to study the constraints which hinder the outreach of institutional credit to such vulnerable groups. Since the problems of farmers in developed countries are different from those in developing countries (Jansson et al., 2013) and given the crucial importance of agriculture sector in developing economies, this study has reviewed relevant literature on agriculture credit in emerging and developing economies. Further, the countries are categorized as "emerging and developing economies" by International Monetary Fund's (IMF) "World Economic Outlook Report 2015". 


\section{The Conceptual Framework}

Agriculture sector is a major contributor of GDP of agriculture-based economies as compared to other sectors of the economy and is a primary source of livelihood for more than half of their total workforce (Mondiale, 2008).

Credit is needed as an important indirect input among others to enhance productivity in agriculture (Sriram, 2007; Das et al., 2009). With modernization and mechanization of farming systems, farming communities require more farm investment. Since most of the farmers in developing countries are small and marginal with fragmented land holdings, they need credit for such investment. Due to lower rate of savings in these economies, the farmers lack sufficient owned-equity and hence resort to external borrowings (Chisasa \& Makina, 2012).

Most of the farming households are faced with paucity of funds at their end. To fulfill their credit requirements, both institutional and non-institutional of finance are available in a developing economy (Singh et al., 2001). When credit is not available on time and at reasonable rates from institutional (formal) sources, farmers are forced to pay exorbitant rates of interest to non-institutional (informal) lenders (Reddy, 2012; Chaudhuri \& Gupta, 1996). Traditionally when agriculture was mainly subsistence based, informal moneylenders used to cater to credit needs of farmers which were comparatively small. After the Green Revolution across the world which initiated tremendous changes in the cropping pattern, the credit needs of farmers have increased spontaneously; and it was during this period that institutional sources of credit emerged as major players. This was the era when subsistence cropping was replaced by cash cropping. Later on, micro-finance emerged as an effective tool of providing credit to the rural communities (Pradhan, 2013). Figure 1 shows the principal sources of credit available to farming communities of an economy. Credit from institutional sources include credit from setup of institutional framework with Apex bank of the country at the top and institutions covered under its purview including specific bodies established for agricultural development of the nation, commercial banks, co-operative banks, regional rural institutions, whereas the non-institutional sources cover credit from unorganized sector like friends, relatives, big landlords, contractors which are not part of the institutional setup. In the mid-way of institutional and non-institutional agencies, lies the semi-formal setup of micro-finance - the provision of a range of financial and non-financial services to group members based on joint liability. While the financial services of micro-finance institutions (MFI) include providing loans (generally in small amounts) to group members, insurance cover, provision of savings; the non-financial services include training and self-employment programs at an affordable cost (Morduch, 1999).

Figure 2 highlights the components covered under the scope of institutional credit. While the direct credit includes all short medium and long term loans for agriculture and allied activities to farmers with direct responsibility of repayment to the lending agency, indirect credit on the other hand includes indirect farmer benefits through subsidized farm inputs. In case of indirect credit, the farmers are under indirect repayment responsibility to the lending agency through fertilizer dealers, corporations, input supplier.

Despite its crucial importance and efforts by government, there exists shortage of agriculture credit in relation to its demand by farming communities. This unmet demand paves way for indigenous lenders as a source of finance for farmers. In this regard, this paper is an attempt to present the financing problems/constraints of farmers in developing economies as reported in literature. A comprehensive review of agricultural credit in various developing economies in the world has been presented covering a time span of twenty years during 1995 to 2015. Published and unpublished literature has been surveyed to analyze determinants, status and performance, determinants of agriculture credit in various countries included in the study.

\section{Rationale and Scope of the Study}

In the recent years, there has been a growing concern about farmer distress, productivity in the agriculture sector amidst rising concerns over food security and sustainability in agriculture. Besides the crucial importance and significant contribution of agriculture in overall GDP of agriculture-based developing economies, the situation of farmers especially the small and marginal ones is still vulnerable. Farmer distress and suicides are very common in countries particularly India and China. Both natural and manmade factors are responsible for such acts. The natural factors include loss of income due to natural calamities of flood, drought, crop failure due to prevalence of pests and diseases etc. which are not in control of mankind; whereas manmade factors can be controlled to an extent and include factors like burden of debt, low return for production due to inefficient marketing and unavailability of resources, higher cost of production due to use of outdated technologies in the production process. Besides considerable efforts and interference by the respective governments, the non-institutional sources of credit have deep roots in the rural credit markets of such economies thereby jeopardizing the prevalence and growth of institutional sources of credit. Several welfare schemes initiated by the governments like loan waiver schemes during crop failure, agricultural crop insurance etc. are not available to vulnerable 
groups including small and marginal farmers which actually need it thereby making their situation miserable. The exclusion of several vulnerable groups from the formal financial services may lead to their social exclusion in the long-run. The provision of timely access to adequate credit may not only help to uplift the situation and living standards of the farming communities but may also raise the production levels in an economy thereby accelerating its GDP growth and hence sustainable development in the long run. The question of whether it is a matter of choice or compulsion to use non-institutional sources of finance is still vague. In light of the above, this paper is an attempt to analyze and present various issues pertaining to agriculture credit at a single place. Relevant literature has been reviewed, classified and presented based on several themes. Literature on the following issues pertaining to agriculture credit has been presented and analyzed in this study -determinants of source and quantum of agriculture credit, gender issues, status, performance and current issues in agriculture credit, impact of agriculture credit on productivity, rationing in rural credit markets, repayment issues in agriculture credit, impact of reforms on agricultural credit and emergence of alternative sources of finance in agriculture.

\section{Objectives of the Study}

The broad objective of this paper is to present the studies on agriculture credit in an organized and easily interpretable way by systematically arranging various published and unpublished studies. The idea is to segregate the reviewed studies into suitable categories based on year, focus area, source of publication, country of study and analyze them accordingly. This paper can serve help for future researchers, policy makers by presenting several inter-related aspects related to agriculture credit at one place. Studies related to issues of determinants of agriculture credit, rationing in credit markets, repayment issues and certain related issues have been analyzed. In particular, this study may help policy makers/bankers/lending institutions of the country on which they are based in taking balanced review of status and performance of agriculture credit. A total of 110 studies published across the world on developing economies have been reviewed for the period 1995 to 2015 . The paper also suggests the future prospects for research in agriculture credit markets of these de veloping nations.

\section{Break-Up of Literature on Agriculture Credit}

After carefully examining all 110 papers, the next step was to classify the literature into suitable categories with internal homogeneity within each category. A comprehensive snapshot of all the reviewed studies is given at end of the paper (Table A1). All analysis, tables and figures of this paper are based on Table A1. On the basis of review, the literature has been classified according to the following themes:

(1) Year-wise classification of studies;

(2) Region-wise classification of studies;

(3) Country-wise classification of studies;

(4) Source-wise classification of studies;

(5) Classification based on type of research.

\subsection{Year-Wise Classification of Studies}

Table I gives the year wise classification of reviewed studies for the period 1995 to 2015 . Figure 3 is a graphical presentation of year-wise publication of reviewed studies. A glance at this figure shows that more papers have been reviewed from recent years thereby indicating the increased importance gained by agriculture sector in more recent years. The maximum no. of reviewed studies is for the year 2012 (19), followed by the year 2013 (16) and 2014 (14) (figures in parenthesis show the no. of studies reviewed during that particular year). It can be noticed that the number of studies have been increasing particularly after the year 2006. In the Indian context, it was the period when its government attempted major efforts to promote financial inclusion in the country.

\subsection{Region-Wise Classification of Studies}

The reviewed studies have been further classified on the basis of geographic region of the world to which a particular country of study belongs. The maximum number of reviewed studies is from East Asia (6), followed by South Asia (4) and East Africa (4) (figures in parenthesis show the number of studies reviewed for the respective region). In East and South Asia regions, majority of the population is dependent on agriculture and therefore a lot of research has been done on agriculture sector of these regions.

\subsection{Country-Wise Classification of Studies}

We have further classified the literature on agricultural credit on the basis of country on which the study is based. 
Table II shows the list of countries on which the reviewed studies are primarily based. A good number of researches have been carried out in various parts of the world. India tops the list with 36 studies, followed by Nigeria (20), Pakistan (09) and so on (figures in parenthesis represent the number of studies in that particular country). Figure 5 shows the country wise publications of the reviewed studies. It can be observed that agriculture sector in developing countries is gaining a reasonably good attention of researchers.

\subsection{Sources of Publication}

Table III gives a comprehensive snapshot of distribution of various sources of publication from where the studies have been retrieved. The most frequent sources of publication are Agricultural Economics Research Review (9); followed by Journal of Development Economics (6), Economic and Political Weekly (5) and so on (figures in parenthesis represent the number of publications in respective journal). A variety of journals have published research in agriculture as the agriculture sector is related to several other sectors of the economy and it affects and gets affected by changes in these sectors.

\subsection{Classification Based on Type of Research}

Here the reviewed literature has been classified on the basis of methodologies adopted in research. For this purpose, the literature has been classified into four categories namely-conceptual, descriptive, empirical and exploratory cross sectional studies. Conceptual studies are those which cover the basic and fundamental concepts of functioning (in rural markets). Descriptive studies give explanation and description of status, content/process and performance issues. Empirical studies cover data from existing sources to estimate and evaluate relationships among various variables. Studies based on primary data collected through surveys are defined as exploratory cross sectional. Table IV gives the distribution of studies according to type of research. Figure 6 shows the percentage distribution of the same. Most frequent methodology used in the literature is exploratory cross sectional (61), followed by empirical (22) (figure in parenthesis represent the number of studies employing a particular methodology).

\section{Focus Area of Research}

This section of paper presents the break-up of literature on the basis of the focus area of research on agriculture credit. Table $\mathrm{V}$ represents focus areas of the reviewed studies. Identifying determinants of agricultural credit is the focal point of most of the studies. Notations "a-i" show the bifurcation of focus area in literature. "a" represents the determinants of sources and amount of agricultural credit, "b" denotes gender issues in agricultural credit, "c" depicts the status, and performance of agriculture credit in developing nations, "d" shows the impact of agriculture credit on output and productivity, "e" represents studies which focus on rationing of rural credit markets, "f" represents studies related to repayment issues in agricultural credit, " $\mathrm{f}$ " shows studies focusing on the role of Islamic Banking in agriculture credit, "g" depicts studies on agriculture credit via micro finance institutions, " $h$ " represents studies which focus on the performance of agriculture credit in developing countries during pre and post reform periods. Figure 7 depicts the percentage distribution of focus area of reviewed studies.

\subsection{Determinants of Agricultural Credit}

Several researchers in the past have tried to identify the factors which significantly influence the household's decision for choice of a particular source of agricultural credit (Akpan et al., 2013; Salami \& Arawomo, 2013; Yuan et al., 2011). Several variables (factors) have been used in the literature by eminent researchers to analyze their impact on farmer household's decision.

\subsubsection{Factors Affecting Quantum and Source of Agricultural Credit}

On the basis of observation of reviewed studies, we found a variety of factors which have significant impact on a household's decision to opt for a particular source of credit. On the basis of review, these factors were classified into three categories based on common attributes as depicted in Table VI. The most common individual specific factors include caste, education, marital status of the household, contact with extension agents, years of experience in farming, land size, gender, contact with large landholders etc. (Aliero \& Ibrahim, 2011; Dzadze et al., 2012; Sebopetji \& Belete, 2009; Akudugu, 2012; Akpan et al., 2013).

\subsubsection{Techniques Used to Identify Determinants of Agriculture Credit}

Different researchers used various techniques to identify the determinants of access to different sources of agricultural credit. Table VII gives a brief view on techniques used in the literature. A large number of researchers used logistic regression to determine the impact of various socio-economic variables on the access to credit (Chauke et al., 2013; Ololade \& Olagunju, 2013; Hananu et al., 2015). Logistic regression model can be 
classified into the following:

(1) Binary logit model;

(2) Multinomial logit model;

(3) Ordered logit model.

While binary logit model is applied where the outcome has binary outcome (either 0 or 1), multinomial logit regression is applied where the outcome has more than two categories (Mpuga, 2010). Here the choice of reference category is arbitrary and this can be used as base category to facilitate comparison between "N" numbers of groups. While ordered logit model is used where the dependent variable has more than two outcomes (categories) having sequential order (Nouman et al., 2013). The outcome i.e. odds ratio gives the magnitude of change in dependent variable for changes in various independent variables (Kosgey, 2013; Baiyegunhi \& Fraser, 2014).

Probit modeling has also been used by a fairly good number of studies to model the probabilities of access to a particular source of finance (Sen \& Prajapati, 2013; Datta \& Ghosh, 2013; Sebopetji \& Belete, 2009). Both logit and probit models have been used in the literature. These are specific cases of modeling when the dependent variables cannot be measured on a metric scale rather it is categorical in nature (Bhanot et al., 2012). Pal and Laha (2014) used quantile regression along with Ordinary least squares method to get an estimate of total credit across various conditional quantiles of borrower groups.

\subsection{Gender Issues in Agriculture Credit}

Studies have investigated the impact of gender on the quantum and sources of agriculture credit. The formal credit was found to be biased against women. The factors affecting the choice of source of finance are different for males and females (Jeiyol et al., 2013; Akugudu et al., 2009). Goetz and Gupta (1996) assert that self-financed institutions in rural areas are more concerned about the quantitative aspects of granting credit to women, while the qualitative aspects like use of credit are not taken care of. Kabeer (2001) documents that loans directed to women have more chances of improving their personal and social benefits. Women are biased than men in terms of access to credit and such inequality is the most insidious form of inequalities (Schuler et al., 1996; Ogunlela \& Mukhtar, 2009).

\subsection{Impact of Agriculture Credit on Output and Productivity}

Literature seems to be divided on the issue of the impact of agriculture credit on agricultural output. On reviewing the literature, it was concluded that the studies can be segregated into two categories:

(1) Agriculture credit has positive and significant impact on agricultural output; and

(2) Impact of agriculture credit on agricultural output cannot be directly established;

While some studies in literature find the direct and significant impact of agriculture credit on output (Bashir et al., 2010; Iqbal et al., 2003; Saleem \& jan, 2011; Rima, 2014; Villanueva, 2014; Ekwere \& Edem, 2014), some others hold that the impact of agricultural credit on farm output cannot be directly established (Sriram, 2007; Hussain, 2012; Zuberi, 1989; Sjah et al., 2003). Ahmad (2011) and Raza and Siddiqui (2014) insist that it is indirect credit to agriculture which has significant impact on agricultural output and not direct credit. De rosary et al. (2014) used simultaneous equation modeling to see the impact of credit on economic functions like production, consumption and investment of households. Duy (2012) applied stochastic frontier analysis and quintile regression and found positive impact of institutional and non-institutional credit on farm output and production efficiency. Similarly, Xi and $\mathrm{Li}$ (2007) used quintile regression to see the impact of formal and informal credit on income and efficiency. Binam et al. (2004) estimated technical efficiency of various categories of farmers and found that efficiency differences are significantly influenced by the amount of agricultural credit utilized in production. Technical efficiency of farmers includes factors like flow of information, access to better infrastructure facilities, farmer's expertise in management of resources and availability of required funds (Iqbal et al., 2003; Chisasa \& Makina,2013). Obilor (2013) applied regression analysis and found that credit allocation to agriculture had significant positive result on productivity. Dong et al. (2010) used probit modeling to determine the relationship between various socio-economic variables and credit condition of households and found that agricultural productivity can be improved with increased use of credit. Owuor and Shem (2012) used switching regression model which is estimated by employing Heckman sample correction method and found significant impact of agriculture credit on production and various input use.

A large number of studies have employed co integration to see the causality between agriculture credit and output. While some findings suggest positive significant impact of agricultural credit on output (Ammani,2012; 
Okulegu et al., 2014; Ihugba et al., 2013), some other studies reject this hypotheses (Oyakhilomen et al., 2012; Musuna \& Muchapondwa, 2008). Table VIII shows the distribution of studies used in the literature to analyze the impact of agricultural credit on farm output. In the literature, Cobb-Douglas production function has been widely used, followed by Granger causality and Co integration. The other approaches include correlation, probit modeling and mixed approaches.

Researchers also employed stochastic frontier analysis to see the impact of agricultural credit on productivity (Liu, 2006; Dolisca \& Jolly, 2008; Nisrane et al., 2011; Kebede, 2001; Chiona et al., 2014). Several studies have used Cobb-Douglas production function to see the impact of agricultural credit on productivity (Sriram, 2007; Bashir et al., 2010; Iqbal et al., 2003; Saleem \& Jan, 2011, Rima, 2014). It is a production function which represents the relationship between output and a number of input variables (Chisasa \& Makina, 2013). To see the impact of credit or other variables, it is log-transformed to take the following form:

$$
\operatorname{LnY}=\beta 0+\beta 1 \operatorname{LnX} 1 \ldots \beta n \operatorname{LnXn}+\varepsilon t
$$

Here $\operatorname{Ln} Y$ represents the $\log$ of agricultural output, $\beta 0$ represents constant term, $\beta 1$ to $\beta \mathrm{n}$ are beta coefficients presenting partial elasticity of various explanatory variables, et represent random error term. Figure 8 shows the most common input variables used to determine their impact on output. Sial et al. (2011) and Iqbal et al. (2003) used dummy variable along with others to see the impact of various uncertainties like drought or floods on agricultural output and found significant negative relation showing decrease in agricultural output during bad years.

\subsection{Rationing in Credit Markets}

Literature is full of evidences to show that well-functioning and efficient rural credit markets can promote rural household's income level and thereby reduce poverty by promoting equitable distribution of resources. Besides institutional setup of rural credit markets, a large number of non-institutional lenders are also present in rural credit markets. As credit from institutional sources is rationed in these countries, rural households are constrained by credit severely (Rui \& Xi., 2010; Kochar, 1997; Carter, 1988). Credit rationing is a situation when those who need credit do not get it in adequate quantity (Jansson et al., 2013). A large number of studies have tried to determine the reasons why the credit markets are rationed (Hashi \& Toci, 2010; Weber \& Musshoff, 2012; Jaffee \& Stiglitz, 1990; Petrick, 2005).

The question that "is it choice or necessity" to resort to non-institutional sector has been addressed by several authors differently. Chaudhuri and Gupta (1996) assert that market for informal loans is created due to delay in disbursing formal loans and that the effective interest on loan from formal sector is same due to incorporation of bribe amount in formal credit which is paid by farmers to avoid delay. Beaman et al. (2014) find that large landholders who have higher returns to their investment choose their source of finance independently since institutional and non-institutional lenders both are ready to lend money to them. Kochar (1997) finds that the extent of rationing is much lesser than what it has been assumed to be and that credit supplied to rural households is less because it is not much demanded. Basu (1997) asserts that credit by formal sources is rationed due to the inherent risk present in agriculture and allied activities, thereby reducing the probability of earnings. Further it is the "congruence of interest" between landlord and tenants which gives birth to loan agreement. Bose (1998) argues that when moneylenders are not fully aware of the likelihood of default by various classes of borrowers, the provision of subsidized credit by banks can lead to adverse "composition effects" which deteriorate the availability of loans in unorganized sector. Guirkinger (2008) found that it is not rationing by formal sector rather lower transaction costs which drive rural households to informal sector. Such lower costs are enjoyed by informal lenders due to proximity and economies of scope.

Credit rationing has deep roots in agriculture sector as compared to other sectors of an economy (Weber \& Musshroff, 2012). Rationing of credit causes a significant loss in income levels and consumption expenditure of rural households (Li et al., 2013). Stiglitz and Weiss (1981) explain credit rationing in terms of agency issues:

(1) adverse selection;

(2) moral hazard.

Adverse selection occurs in rural credit markets when the formal credit institutions are not fully aware of borrower's credit worthiness and therefore credit worthy borrowers are left when banks try to mitigate the risk of default by raising the rate of interest (Klonner \& Rai, 2005; Binswanger \& Deininger, 1997; Ghosh et al., 2000). While moral hazard occurs as a result of dominance of large and wealthy landholders while obtaining cheap credit since they possess more resources to offer as collateral and as a result the poor borrowers are left away (Simtowe et al., 2006). Figure 9 has diagrammatically presented the agency problem. 


\subsection{Repayment Issues in Agriculture Credit}

Apart from rationing in credit markets, studies have also tried to analyze repayment issues in agriculture credit. Banks do not lend to poor groups due to fear of non-repayment and increase in their non-performing assets. A large number of studies have tried to investigate various factors which affect repayment performance of borrowers in rural markets. Kohansal and Mansoori (2009) applied logit regression to identify factors influencing repayment and found that farming experience, income of borrower, loan size, value of collateral offered as security have significant positive impact on repayment performance of borrowers while interest rate, total application costs and number of installments to repay loan impact it negatively. Figure 10 shows the classification of factors affecting repayment schedules. Various factors affect repayment performance of borrowers in the rural credit markets. We have classified these factors into two broad categories, namely:

(1) Social factors;

(2) Economic factors and;

(3) Contract-specific factors.

While the most common social factors affecting repayment rate among borrower households are age, education, gender, marital status, experience of the household, household size, diversion of loan due to family commitments, incidence of crop diseases and pests, farm size, monopoly power created by informal lenders in markets, use of modern machinery and equipments, contact with extension agents, social relations of the borrower households.

Economic factors include interest rate on loan, income of the household, loan size, value of the collateral offered as security, total application costs, off-farm income, net profit, market price fluctuations, market value of livestock, fluctuations in commodity prices, amount spent on hiring equipment (Kohansal \& Mansoori, 2009; Weber et al., 2014).

Contract-specific factors include various terms and conditions specific to a particular loan contract like lender's supervision on utilization of loan, number of repayment installments, down-payment of loan, length of waiting time for receiving the loaned amount from lender, length of repayment period.

\section{Policy Issues and Implications}

In line with the objective of presenting and classifying the reviewed studies, several issues relating to agriculture credit in developing countries have been discussed. The review presented in this study can be used by policy makers/banks/researchers to judge the performance of agriculture credit in these nations and analyze the situation of agriculture sector in this direction. A review of the relevant literature highlights that the interest of researchers has been growing towards this topic over the past few years. However, there exist huge disparities in the number of publications in these countries. Determining the factors which affect household's choice of a particular source of finance has been heavily emphasized by eminent researchers in the literature. Several factors have been used to study this relationship at the micro-level, the most prominent of which are- literacy, land size, marital status, distance from a lending institution, age of the borrower, caste, religion, the value of assets owned by the household. A majority of studies have reported significant impact of literacy, size of landholdings and household assets on opting for the source of financing agriculture. Their findings reassert the importance of literacy especially financial literacy in covering the hitherto deprived groups under the ambit of institutional setup of an economy and in uplifting their living standards. Household assets and size of landholdings represent the value which the households possess and can offer as collateral security while procuring loan. As banks perceive clients with more asset value as credit-worthy, they are more inclined towards such borrowers than their other counterparts. Therefore, it is important for the governments and other regulatory authorities to keep a regular and timely check on lending activities of financial institutions covered under their ambit and to encourage banks for social banking initiatives rather than class banking. In the development process of an economy, it is important to implement policies at the bottom level rather than at the top only. Next, the impact of direct institutional credit is found to be associated with the productivity levels by majority of studies which pinpoints the discrepancies in indirect credit mechanism. The failure of cooperative banking in India is one such example. Banking institutions in an economy should be promoted in such a way that they are sustainable in the long-run and their dependence on donors/state governments is minimal. Micro-finance and Islamic Banking appear to be alternate source of financing agriculture and find the mid-way of institutional and non-institutional setup of rural market markets. But micro-finance institutions are perhaps in their nascent stage and their management needs to be nurtured. Lack of awareness among masses about their working and lack of trust pose restrictions on their financial and operational sustainability in the long-run. 


\section{Conclusions and Way to Future Research}

This study has reviewed 110 research papers on agriculture credit between 1995 and 2015 from various journals, working papers and several other published and unpublished sources. Studies on developing countries relating to agriculture credit have been systematically presented and reviewed. Agriculture credit is a topic of considerable interest in countries particularly India, Nigeria and Pakistan. After reviewing the studies, a noticeable growth in the number of studies have been observed particularly after the year 2006. The agriculture sector has assumed more importance in recent years amid rising concerns about food security and population pressures. In the Indian context, this was the period when government focused extensively on the increased use of institutional credit and several measures policy measures were initiated to promote financial inclusion. Majority of the studies are focused on determinants of sources and amount of agriculture credit by employing exploratory cross-sectional research. However, less research has been done on identifying the supply side determinants/constraints of agriculture credit. This could be an area of future research. So far, the implementation of policies framed by the government has lacked the desirable commitment from banks/financial institutions which are in close proximity with farmers. It appears that in order to make the credit delivery system inclusive, efforts need to be initiated at the bottom level rather at top. Further, this study is limited to developing countries only, therefore future research can be undertaken by including developed nations which remain uncovered in this study. Studies by Duy (2012), Liu (2006) applied stochastic frontier analysis to analyze the impact of agriculture credit on farm output and production efficiency. Application of stochastic frontier analysis in agriculture output is paving a new way for future research. To analyze the level of integration between credit and output, new techniques like Auto regressive distributed lags (ARDL) can be applied in future research. Micro-finance institutions appear to be a good option which can fulfill the gap for institutional credit but micro-finance institutions themselves are faced with internal conflicts of interest and discrimination and paucity of funds at their end. Literature seems less focused on reporting such discrepancies and how MFIs can be made sustainable. The policy implications and impact of microfinance on agricultural production and household income can be studied further.

\section{References}

Admassie, A. (2004). A Review of the performance of agricultural finance in Ethiopia: Pre-and-post reform periods. In International Conference on Agrarian Constraints and Poverty Reduction, 17-18.

Admasu, A., \& Paul, I. (2010). Assessment on the mechanism and challenges of small scale agricultural credit from commercial banks in Ethiopia: The case of Adaá Liben Woreda Ethiopia. Journal of Sustainable Development in Africa, 12(3), 323-304.

Afolabi, J. A. (2010). Analysis of Loan Repayment among Small Scale Farmers in Oyo State, Nigeria. Journal of Social Sciences, 22(2), 115-119.

Ahmad, N. (2011). Impact of institutional credit on agricultural output: A case study of Pakistan. Theoretical and Applied Economics, 10(10), 99-120.

Akpan, S. B., Patrick, I. V., Udoka, S. J., Offiong, E. A., Okon, U. E., \& Comment, G. (2013). Determinants of Credit Access and Demand among Poultry Farmers in Akwa Ibom State, Nigeria. American Journal of Experimental Agriculture, 3(2), 293-307. http://dx.doi.org/10.9734/AJEA/2013/2810

Akudugu, M. A. (2012). Estimation of the Determinants of Credit Demand by Farmers and Supply by Rural Banks in Ghana's Upper East Region. Asian Journal of Agriculture and Rural Development, 2(2), 189-200.

Akudugu, M. A., Egyir, I. S., \& Mensah-Bonsu, A. (2009). Women farmers' access to credit from rural banks in Ghana. Agricultural Finance Review, 69(3), 284-299. http://dx.doi.org/ 10.1108/00021460911002671.

Aliero, H. M., \& Ibrahim, S. S. (2011). An analysis of farmers' access to formal credit in the rural areas of Nigeria. African Journal of Agricultural Research, 6(17).

Ammani, A. A. (2012). An investigation into the relationship between agricultural production and formal credit supply in Nigeria. International Journal of Agriculture and Forestry, 2(1), 46-52. http://dx.doi.org/10.5923/j.ijaf.20120201.08

Asanoy, A. (2004). Effects of agricultural credit and microfinance on expenditure patterns in Yemen (Doctoral dissertation, Universiti Putra Malaysia). Retrieved from http://psasir.upm.edu.my/6130

Augwumba, C. O., Omojola, J. T., \& Azifuaku, E. N. (2014). Credit Access and Repayment by Farmer-Beneficiaries of Microfinance Banks' Loans in Idemili North Local Government Area of Anambra State, Nigeria. Journal of Environmental Science, Computer Science and Engineering and Technology, 3(4), 1733-1741. 
Ayegba, O., \& Ikani, D. I. (2013). An Impact Assessment of Agricultural Credit on Rural Farmers in Nigeria. Research Journal of Finance and Accounting, 4(18), 80-89.

Badiru, I. O. (2010). Review of small farmer access to agricultural credit in Nigeria. International Food Policy Research Institute, Policy note, (25).

Baiyegunhi, L. J. S., \& Fraser, G. C. (2014). Smallholder farmers' access to credit in the Amathole District Municipality, Eastern Cape Province, South Africa. Journal of Agriculture and Rural Development in the Tropics and Subtropics, 115(2), 79-89.

Balogun, O. L., \& Yusuf, S. A. (2011). Determinants of demand for microcredit among the rural households in South-Western States, Nigeria. Journal of Agriculture and Social Sciences, 7, 41-48.

Barslund, M., \& Tarp, F. (2008). Formal and informal rural credit in four provinces of Vietnam. The Journal of Development Studies, 44(4), 485-503. http://dx.doi.org/10.1080/00220380801980798

Bashir, G., Ashaq, A., Ganie, H., Ummer, M., \& Padder, J. (2013). A study on institutional credit to agriculture sector in India. International Journal of Current Research and Academic Review, 1(4), 72-80.

Bashir, M. K., Mehmood, Y., \& Hassan, S. (2010). Impact of agricultural credit on productivity of wheat crop: Evidence from Lahore, Punjab, Pakistan. Pakistan Journal of Agricultural Sciences, 47(4), 405-409.

Bashiru, M., Dumayiri, M., \& Sabutey, G. T. (2014). Analysis of the sources of Farm investment Credit in the Upper West region of Ghana. International Journal of Current Research and Academic Review, 2(5), 1-15.

Basu, S. (1997). Why institutional credit agencies are reluctant to lend to the rural poor: A theoretical analysis of the Indian rural credit market. World Development, 25(2), 267-280. Retrieved from http://dx.doi.org/10.1016/S0305-750X(96)00103-9

Beaman, L., Karlan, D., Thuysbaert, B., \& Udry, C. (2014). Self-Selection into Credit Markets: Evidence from Agriculture in Mali (No. W20387). National Bureau of Economic Research. http://dx.doi.org/10.3386/w20387

Bhanot, D., Bapat, V., \& Bera, S. (2012). Studying financial inclusion in north-east India. International Journal of Bank Marketing, 30(6), 465-484. http://dx.doi.org/10.1108/02652321211262221

Binam, J. N., Tonye, J., Nyambi, G., \& Akoa, M. (2004). Factors affecting the technical efficiency among smallholder farmers in the slash and burn agriculture zone of Cameroon. Food policy, 29(5), 531-545. http://dx.doi.org/10.1016/j.foodpol.2004.07.013

Binswanger, H. P., \& Deininger, K. (1997). Explaining agricultural and agrarian policies in developing countries. Journal of Economic Literature, 35, 1958-2005.

Bista, D. R., Kumar, P., \& Mathur, V. C. (2012). Progress and Performance of Kisan Credit Card Scheme with a case study of Bihar. Agricultural Economics Research Review, 25(1), 125-135.

Bolarinwa, K. K., \& Fakoya, E. O. (2011). Impact of farm credit on Farmers' socio-economic status in Ogun State, Nigeria. Journal of Social Science, 26(1), 67-71.

Bose, P. (1998). Formal-informal sector interaction in rural credit markets. Journal of Development Economics, 56(2), 265-280. http://dx.doi.org/10.1016/S0304-3878(98)00066-2

Bruhn, M., \& Love, I. (2014). The real impact of improved access to finance: Evidence from Mexico. The Journal of Finance, 69(3), 1347-1376. http://dx.doi.org/10.1111/jofi.12091

Carter, M. R. (1988). Equilibrium credit rationing of small farm agriculture. Journal of Development Studies, 28(1), 83-103. http://dx.doi.org/10.1016/0304-3878(88)90015-6

Chakrabarty, D., \& Chaudhuri, A. (2001). Formal and informal sector credit institutions and interlinkage. Journal of Economic Behavior and Organization, 46(3), 313-325. http://dx.doi.org/10.1016/S0167-2681(01)00180-9

Chattopadhyay, S. K. (2011). Financial inclusion in India: A Case Study of West Bengal. RBI Working Paper Series No. 8, Department of Economic and Policy Research, Reserve Bank of India, Mumbai.

Chaudhuri, S., \& Gupta, M. R. (1996). Delayed formal credit, bribing and the informal credit market in agriculture: A theoretical analysis. Journal of Development Economics, 51(2), 433-449. http://dx.doi.org/10.1016/S0304-3878(96)00407-5

Chauke, P. K., Motlhatlhana, M. L., Pfumayaramba, T. K., \& Anim, F. D. K. (2013). Factors influencing access 
to credit: A case study of smallholder farmers in the Capricorn district of South Africa. African Journal of Agricultural Research, 8(7), 582-585.

Chavan, P. (2008). Gender Inequality in Banking Services. Economic and Political Weekly, 43(47), 18-21.

Chiona, S., Kalinda, T., \& Tembo, G. (2014). Stochastic Frontier Analysis of the Technical Efficiency of Smallholder Maize Farmers in Central Province, Zambia. Journal of Agricultural Science, 6(10), 108-118. http://dx.doi.org/10.5539/jas.v6n10p108

Chisasa, J., \& Makina, D. (2012). Trends in credit to smallholder farmers in South Africa. International Business \& Economics Research Journal, 11(7), 771-784.

Chisasa, J., \& Makina, D. (2013). Bank credit and agricultural output in South Africa: A Cobb-Douglas empirical analysis. International Business \& Economics Research Journal, 12(4), 387-398.

Coleman, B. E. (1999). The impact of group lending in Northeast Thailand. Journal of Development Economics, 60(1), 105-141. http://dx.doi.org/10.1016/S0304-3878(99)00038-3

Das, A., Senapati, M., \& John, J. (2009). Impact of agricultural credit on agriculture production: An empirical analysis in India. Reserve Bank of India Occasional Papers, 30(2), 75-107.

Das, T. (2015). Informal finance-A study of north east India. Journal of Rural Development, 34(1), 17-30.

Datta, S., \& Ghosh, A. (2013). Explaining Access to Credit by Rural Households: Results based on a Study of Several States in India. Retrieved from http://hdl.handle.net/123456789/11409

De Rosari, B. B., Sinaga, B. M., Kusnadi, N., \& Sawit, M. H. (2014). The Impact Of Credit And Capital Supports On Economic Behavior Of Farm Households: A Household Economic Approach. International Journal of Food and Agricultural Economics, 2(3).

Devaraja, T. S. (2011). An Analysis of Institutional Financing and Agricultural Credit Policy in India. University of Mysore. Retrieved from http://sibresearch.org/uploads/2/7/9/9/2799227/institutional_financing_-_devaraja.pdf

Diagne, A., \& Zeller, M. (2001). Access to credit and its impact on welfare in Malawi. Research report no. 116. International Food Policy Research Institute.

Dolisca, F., \& Jolly, C. M. (2008). Technical efficiency of traditional and non-traditional crop production: A case study from Haiti. World Journal of Agricultural Sciences, 4(4), 416-426.

Dong, F., Lu, J., \& Featherstone, A. M. (2010). Effects of credit constraints on productivity and rural household income in China. Center for Agricultural and Rural Development, Iowa State University.

Duy, V. Q. (2012). The role of access to credit in rice production efficiency of rural households in the Mekong Delta, Vietnam. Center for Asian Studies Discussion Paper No. 284.

Duy, V. Q. (2013). Is the repayment performance of farmers better than that of non-farmers? A case study of borrowers of formal bank credit in the Mekong Delta, Vietnam. Centre for ASEAN Studies Discussion Paper No. 88.

Dzadze, P., Osei-Mensah, J., Aidoo, R., \& Nurah, G. K. (2012). Factors determining access to formal credit in Ghana: A case study of smallholder farmers in the Abura-Asebu Kwamankese district of central region of Ghana. Journal of Development and Agricultural Economics, 4(14), 416-423.

Ekwere, G. E., \& Edem, I. D. (2014). Evaluation of Agricultural Credit Facility in Agricultural Production and Rural Development. Global Journal of Human-Social Science Research, 14(3), 19-26.

Fakayode, S. B., Adewumi, M. O., Salau, S. A., \& Afolabi, O. A. (2009). On-Lending Credit Scheme to Crop Farmers in Nigeria: An Appraisal of Ekiti State Agricultural Credit Agency (ESACA) Scheme. Journal of Agriculture, Biotechnology and Ecology, 2(3), 286-294.

Fan, S., Chen-Kang, C., \& Mukherjee, A. (2005). Rural and urban dynamics and poverty: Evidence from China and India. Food Consumption and Nutrition Division, Discussion paper no. 196, International Food Policy Research Institute, Washington.

Feder, G., Lau, L. J., Lin, J. Y., \& Luo, X. (1990). The relationship between credit and productivity in Chinese agriculture: A microeconomic model of disequilibrium. American Journal of Agricultural Economics, 72(5), 1151-1157.

Gandhimathi, S., \& Vanitha, S. (2010). Determinants of borrowing behaviour of farmers-A comparative study of 
commercial and co-operative banks. Agricultural Economics Research Review, 23(1), 157-164.

Ghosh, P., Mookherjee, D., \& Ray, D. (2000). Credit rationing in developing countries: An overview of the theory. Readings in the Theory of Economic Development, 383-401.

Giné, X., \& Yang, D. (2009). Insurance, credit, and technology adoption: Field experimental evidence from Malawi. Journal of Development Economics, 89(1), 1-11. http://dx.doi.org/10.1016/j.jdeveco.2008.09.007

Goetz, A. M., \& Gupta, R. S. (1996). Who takes the credit? Gender, power, and control over loan use in rural credit programs in Bangladesh. World Development, 24(1), 45-63. http://dx.doi.org/10.1016/0305-750X(95)00124-U

Golait, R. (2007). Current issues in agriculture credit in India: An assessment. Occasional Paper, 28(1), 79-99. Reserve bank of India, Mumbai.

Guirkinger, C. (2008). Understanding the coexistence of formal and informal credit markets in Piura, Peru. World Development, 36(8), 1436-1452. http://dx.doi.org/10.1016/j.worlddev.2007.07.002

Guirkinger, C., \& Boucher, S. R. (2008). Credit constraints and productivity in Peruvian agriculture. Agricultural Economics, 39(3), 295-308. http://dx.doi.org/10.1111/j.1574-0862.2008.00 334.x

Gulati, A., \& Bathla, S. (2002). Institutional credit to Indian agriculture: Defaults and policy options. Occasional paper no. 23, National Bank for Agriculture and Rural Development, Mumbai.

Hananu, B., Abdul-Hanan, A., \& Zakaria, H. (2015). Factors influencing agricultural credit demand in Northern Ghana. African Journal of Agricultural Research, 10(7), 645-652. http://dx.doi.org/10.5897/AJAR2014.9330

Hashi, I., \& Toci, V. (2010). Financing constraints, credit rationing and financing obstacles: Evidence from firm-level data in south Eastern Europe. Economic and Business Review, 12(1), 29-60.

Hassan, M. T., Sattar, M. A., Tousif, M. A., Nasir, N., Sadiq, M., \& Yasmeen, M. (2012). The Role of Islamic Banking in Agriculture Development in Bahawalpur, Pakistan. International Journal of Learning and Development, 2(3), 123-138. http://dx.doi.org/10.5296/ijld.v2i3.1817

Hussain, A. H. (2012). Impact of credit disbursement, area under cultivation, fertilizer consumption and water availability on rice production in Pakistan (1988-2010). Sarhad Journal of Agriculture, 28(1), 95-101.

Hussain, A., \& Thapa, G. B. (2012). Smallholders' access to agricultural credit in Pakistan. Food Security, 4(1), 73-85. http://dx.doi.org/10.1007/s12571-012-0167-2

Idoge, D. E. (2013). Regionalising Loan Repayment Capacity of Small Holder Cooperative Farmers in Nigeria: Exploring South-South Nigeria. Journal of Biology, Agriculture and Healthcare, 3(7), 176-183.

Ihugba, O. A., Chinedu, N., \& Njoku, A. C. (2013). An assessment of Nigeria expenditure on the agricultural sector: Its relationship with agricultural output (1980-2011). Journal of Economics and International Finance, 5(5), 177-186. http://dx.doi.org/10.5897/JEIF2012.0471

International Monetary Fund. (2015). World Economic and Financial Surveys. World Economic Outlook. Retrieved from http://www.imf.org/external/pubs/ft/weo/2015/01/weodata/ groups.htm

Iqbal, M., Ahmad, M., Abbas, K., \& Mustafa, K. (2003). The Impact of Institutional Credit on Agricultural Production in Pakistan [with Comments]. The Pakistan Development Review, 42(4),469-485.

Izhar, A., \& Tariq, M. (2009). Impact of institutional credit on aggregate agricultural production in India during Post Reform Period. MPRA paper no. 17075, MPRA. Retrieved from http://mpra.ub.uni-muenchen.de/17075/

Jaffee, D., \& Stiglitz, J. (1990) Credit rationing. In B. Friedman, \& F. Hahn (Eds.), Handbook of Monetary Economics, (Vol. 2, pp. 837-888). Amsterdam: North Holland.

Jain, S. (1999). Symbiosis vs. crowding-out: the interaction of formal and informal credit markets in developing $\begin{array}{lllll}\text { countries. Journal of Development } & \text { Economics, } & 59(2), & 419-444 .\end{array}$ http://dx.doi.org/10.1016/S0304-3878(99)00019-X

Jan, I., Munir, S., Usman, A., \& Idrees, M. (2012). Agricultural credit markets in northwest Pakistan: Implications for the development policy. Sarhad Journal of Agriculture, 28(3), 521-529.

Jansson, K. H., Huisman, C. J., Lagerkvist, C. J., \& Rabinowicz, E. (2013). Agricultural Credit Market Institutions: A Comparison of Selected European Countries. Retrieved from 
http://papers.ssrn.com/sol3/papers.cfm?abstract_id=2198808

Jeiyol, E. N., Akpan, S. B., \& Tee, T. N. (2013). Gender Analysis of Access to Credit by Rural Small Scale Farmers in Benue State Nigeria. American International Journal of Social Science, 2(6), 70-78.

Joshi, N., \& Gautam, J. (2014). Inequalities in Flow of Agriculture Credit: A Macro and Micro Level Analysis. http://dx.doi.org/10.2139/ssrn.2509898

Jumrani, J., \& Agarwal, S. (2012). Outreach and Inclusiveness of Formal Agricultural Credit System: Some Reflections. Agricultural Economics Research Review, 25, 445-460.

Kabeer, N. (2001). Conflicts over credit: Re-evaluating the empowerment potential of loans to women in rural Bangladesh. World development, 29(1), 63-84. http://dx.doi.org/10.1016/S0305-750X(00)00081-4

Kebede, T. A. (2001). Farm household technical efficiency: A stochastic frontier analysis. A study of Rice producers in Mardi Watershed in the Western Development Region of Nepal. A Master's Thesis Submitted to Department of Economics and Social Sciences, Agricultural University of Norway.

Khandker, S. R., \& Koolwal, G. B. (2015). How has microcredit supported agriculture? Evidence using panel data from Bangladesh. Agricultural Economics. http://dx.doi.org/10.1111/agec.12185

Kishore, N. K. (2012). Agriculture Credit in India: An Integrated Rural Credit Approach. International Journal of Scientific and Research Publications, 2(3), 1-5.

Klonner, S., \& Rai, A. S. (2005). Adverse selection in credit markets: Evidence from South Indian bidding ROSCAs. Department of Economics, Cornell University. Retrieved from http://eml.berkeley.edu/ webfac/emiguel/e271_s06/klonner.pdf

Knight, T., \& Hossain, F. (2008). Helping the Needy: Factors Influencing the Development of Microfinance in Barbados. University of Manchester Brooks World Poverty Institute. Retrieved from http://papers.ssrn.com/sol3/papers.cfm?abstract_id=1265575

Kochar, A. (1997). An empirical investigation of rationing constraints in rural credit markets in India. Journal of Development Economics, 53(2), 339-371. http://dx.doi.org/10.1016/S0304-3878(97)00020-5

Kohansal, M. R., \& Mansoori, H. (2009). Factors affecting loan Repayment Performance of farmers in Khorasan-Razavi Province of Iran. In Conference on International Research on Food Security, Natural Resource Management and Rural Development, at University of Hamburg, Germany, October 6-8, 2009.

Konare, K. (2001). Challenges to Agricultural financing in Mali. Doctoral dissertation, Michigan State University.

Kosgey, Y. K. K. (2013). Agricultural Credit Access by Grain Growers in Uasin-Gishu Country, Kenya. IOSR-Journal of Economics and Finance, 2(3), 36-52. http://dx.doi.org/10.9790/5933-0233652

Kumar, A., Singh, K. M., \& Sinha, S. (2010). Institutional credit to agriculture sector in India: Status, performance and determinants. Agricultural Economics Research Review, 23(2), 253-264.

Kumar, C., Turvey, C. G., \& Kropp, J. D. (2012). Credit constraint impacts on farm households: Survey results from India and China. http://dx.doi.org/10.2139/ssrn.2034487

Laoubi, K., \& Yamao, M. (2012). The Challenge of Agriculture in Algeria: Are Policies Effective? Bulletin of Agricultural and Fisheries Economics, 12(1), 65-73.

Li, R., Li, Q., Huang, S., \& Zhu, X. (2013). The credit rationing of Chinese rural households and its welfare loss: An investigation based on panel data. China Economic Review, 26, 17-27. http://dx.doi.org/10.1016/j.chieco.2013.03.004

Liu, Y. (2006). Model selection in stochastic frontier analysis: Maize production in Kenya. Paper prepared for presentation at the American Agricultural Economics Association Annual Meeting, Long Beach, California, July 23-26, 2006.

Mandal, S., Datta, K. K., Mohanty, S., \& Mahapatra, B. K. (2005). Risk of financing agriculture in the North-Eastern Hill Region of India with special reference to Meghalaya. Agricultural Economics Research Review, 18, 83-102.

Miller, C. (2011). Microcredit and crop agriculture: New approaches, technologies and other innovations to address food insecurity among the poor. Paper presented at Microcredit Summit, Vallaloid, Spain, November 2011. 
Mohan, R. (2006). Agricultural credit in India: Status, issues and future agenda. Economic and Political Weekly, 42(11), 1013-1023.

Mondiale, B. (2008). Agriculture for development. World Development Report, World Bank, Washington DC.

Morduch, J. (1999). The microfinance promise. Journal of Economic Literature, 37(4), 1569-614. http://dx.doi.org/10.1257/jel.37.4.1569

Mpuga, P. (2010). Constraints in access to and demand for rural credit: Evidence from Uganda. African Development Review, 22(1), 115-148. http://dx.doi.org/10.1111/j.1467-8268.2009.00230.x

Munyambonera, E., Mayanja, M. L., Nampeewo, D., \& Adong, A. (2014). Access and use of credit in Uganda: Unlocking the dilemma of financing small holder farmers. Retrieved from http://hdl.handle.net/10570/4010

Musuna, S., \& Muchapondwa, E. (2008). Will availing credit incentives to Zimbabwean farmers trigger a maize output response? Working paper no.100, School of Economics, University of Cape Town.

Mylott, E. (2009). Urban-rural connections: A review of the literature. Retrieved from http://hdl.handle.net/1957/10574

Nagarajan, G., Meyer, R. L., \& Hushak, L. J. (1995). Segmentation in the informal credit markets: The case of the Philippines. Agricultural Economics, 12(2), 171-181. http://dx.doi.org/10.1016/0169-5150(95)01135-8

Nisrane, F., Berhane, G., Asrat, S., Getachew, G., Taffesse, A. S., \& Hoddinott, J. (2011). Sources of inefficiency and growth in agricultural output in subsistence agriculture: A stochastic frontier analysis. Working paper no. 19, International Food Policy Research Institute.

Nouman, M., Siddiqi, M. F., Asim, S. M., \& Hussain, Z. (2013). Impact of Socio-Economic Characteristics of Farmers on Access to Agricultural Credit. Sarhad Journal of Agriculture, 29(3), 469-476.

Obilor, S. I. (2013). The impact of commercial banks' credit to agriculture on agricultural development in Nigeria: An econometric analysis. International Journal of Business, Humanities and Technology, 3(1), 85-94.

Ogunlela, Y. I., \& Mukhtar, A. A. (2009). Gender issues in agriculture and rural development in Nigeria: The role of women. Humanity and Social Sciences Journal, 4(1), 19-30.

Ojiako, I. A., \& Ogbukwa, B. C. (2012). Economic analysis of loan repayment capacity of smallholder cooperative farmers in Yewa North Local Government Area of Ogun State, Nigeria. African Journal of Agricultural Research, 7(13), 2051-2062.

Okulegu, B. E., Onwe, O. G., \& Okoro, O. T. (2014). Banking sector credit and the performance of the agricultural sector in nigeria (1981-2011). Global Journal of Applied,Management and Social Sciences, 7, $35-55$.

Olagunju, F. I., \& Adeyemo, R. (2007). Agricultural credit and production efficiency of smallscale farmers in south-eastern Nigeria. Agricultural Journal, 2(3), 426-433.

Ololade, R. A., \& Olagunju, F. I. (2013). Determinants of Access to Credit among Rural Farmers in Oyo State, Nigeria. Global Journal of Science Frontier Research, 13(2), 17-22.

Olowa, O. W., \& Olowa, O. A. (2011). Issues, Problems and Policies in Agricultural Credit: A Review of Agricultural Credit in Nigeria. Bangladesh Sociological Society, 8(2), 87-108.

Owuor, G., \& Shem, A. O. (2012). Informal Credit and Factor Productivity in Africa: Does Informal Credit Matter?. In at the International Association of Agricultural Economists Triennial Conference, Foz do Iguaco, Brazil, 18-24 August, 2012.

Oyakhilomen, O., Omadachi, U. O., \& Zibah, R. G. (2012). Cocoa Production-Agricultural Credit Guarantee Scheme Fund Nexus in Nigeria: A Co integration Approach. Russian Journal of Agricultural and Socio Economic Sciences, 3, 28-32.

Pal, D., \& Laha, A. K. (2014). Credit off-take from formal financial institutions in rural India: Quantile regression results. Agricultural and Food Economics, 2(1), 1-20. http://dx.doi.org/10.1186/s40100-014-0009-y

Petrick, M. (2005). Empirical measurement of credit rationing in agriculture: A methodological survey. Agricultural Economics, 33(2), 191-203. http://dx.doi.org/10.1111/j.1574-0862.2005.00384.x 
Pradhan, N. C. (2013). Persistence of Informal Credit in Rural India: Evidence from All-India Debt and Investment Survey and Beyond. Working paper No. 05/2013, Department of Economic and Policy Research, Reserve Bank of India, Mumbai.

Ramakumar, R., \& Chavan, P. (2007). Revival of agricultural credit in the 2000s: An Explanation. Economic and Political Weekly, 42(52), 57-63.

Rao, P. S., \& Priyadarshini, Y. J. (2013). Credit Options to the Rural Poor: Microfinance as a Source of Rural Credit in India. International Journal of Management and Social Sciences Research, 2(4), 8-21.

Raza, J., \& Siddiqui, W. (2014). Determinants of Agricultural Output in Pakistan: A Johansen Co-integration Approach. Academic Research International, 5(4), 30-46.

Reddy, A. A. (2012). Structure of Indebtedness of Households in Semi-Arid Tropics of India. Agricultural Economics Research Review, 25, 473-483. http://dx.doi.org/10.2139/ssrn.2160334

Rima, N. S. (2014). Agricultural Credit flow of Commercial Banks and Impact on Agricultural production in Nepal. Scholars Journal of Art, Humanities and Social Science, 2(2c), 372-376.

Rui, L., \& Xi, Z. (2010). Econometric analysis of credit constraints of chinese rural households and welfare loss. Applied Economics, 42(13), 1615-1625. http://dx.doi.org/10.1080/00036840701721604

Sahu, G. B., \& Rajasekhar, D. (2005). Banking sector reform and credit flow to Indian agriculture. Economic and Political Weekly, 40(53), 5550-5559.

Salami, A., \& Arawomo, D. F. (2013). Empirical Analysis of Agricultural Credit in Africa: Any Role for institutional Factors? Working Paper no.192, African Development Bank, Tunis, Tunisia.

Saleem, M. A., \& Jan, F. A. (2011). The impact of agricultural credit on agricultural productivity in Dera Ismail Khan (District) Khyber Pakhtonkhawa Pakistan. European Journal of Business and Management, 3(2), 38-44.

Satyasai, K. J. S. (2008). Rural credit delivery in India: Structural constraints and some corrective measures. Agricultural Economics Research Review, 21, 387-394.

Satyasai, K. J. S. (2012). Access to Rural Credit and Input Use: An Empirical Study. Agricultural Economics Research Review, 25, 461-471.

Satyasai, K. J. S., \& Badatya, K. C. (2000). Restructuring rural credit co-operative institutions. Economic and Political Weekly, 35(5), 307-330.

Schuler, S. R., Hashemi, S. M., Riley, A. P., \& Akhter, S. (1996). Credit programs, patriarchy and men's violence against women in rural Bangladesh. Social Science and Medicine, 43(12), 1729-1742. http://dx.doi.org/10.1016/S0277-9536(96)00068-8

Sebopetji, T. O., \& Belete, A. (2009). An application of probit analysis to factors affecting small-scale farmers' decision to take credit: A case study of the Greater Letaba Local Municipality in South Africa. African Journal of Agricultural Research, 4(8), 718-723.

Sen, V., \& Prajapati, H. R. (2013). Credit Accessibility of Small and Marginal Farmers in Bundelkhand. International Journal of Human Potential Development, 2(2), 42-50.

Shafiai, M. H. M., \& Moi, M. R. (2015). Financial Problems among Farmers in Malaysia: Islamic Agricultural Finance as a Possible Solution. Asian Social Science, 11(4), 1-16. http://dx.doi:10.5539/ass.v11n4p1

Sharma, B. K., Kumawat, R. C., \& Singh, G. P. (2012). Problems/constraints faced by the farmers in borrowing and by the financial institutions in lending the agricultural loans in Jaipur district Rajasthan. The Journal of Rural and Agricultural Research, 12(2), 46-49.

Shukla, A. N., Tewari, S. K., \& Dubey, P. P. (2012). Performance of direct finance to agriculture according to size of land holdings. The Journal of Rural and Agricultural Research, 12(1), 87-89.

Sial, M. H., Awan, M. S., \& Waqas, M. (2011). Role of institutional credit on agricultural production: A time series analysis of Pakistan. International Journal of Economics and Finance, 3(2), 126-132. http://dx.doi.org/10.5539/ijef.v3n2p126

Simtowe, F., Zeller, M., \& Phiri, A. (2006). Determinants of moral hazard in microfinance: Empirical evidence from joint liability lending schemes in Malawi. In 2006 International Association of Agricultural Economists Conference, Gold Coast, Australia, August 12-18, 2006. 
Singh, K., Kadyian, N., \& Kodan, A. S. (2011). Agriculture Credit in Post World Trade Organization Period in India: Trend, Composition, Issues and Challenges-A Study of Scheduled Commercial Banks. Journal of Management and Information Technology, 3(1), 8-27.

Singh, M. D. V., \& Kant, T. (2014). Bank finance in Agriculture- A study. The Journal of Rural and Agricultural Research, 14(1), 55-58

Singh, R. P., Pandey, A. L., \& Singh, S. K. (2001). Rural credit and participation of credit agencies - An analysis. Indian Cooperative Review, 38(4), 211-220.

Singh, S., Kaur, M., \& Kingra, H. S. (2009). Inadequacies of institutional agricultural credit system in Punjab state. Agricultural Economics Research Review, 22(2), 309-318.

Sjah, T., Cameron, D., \& Russell, I. (2003). Factors contributing to the performance of agricultural credit in Lombok Indonesia. In 14th International Farm Management Congress: Farming at the edge, International Farm Management Congress.

Soubbotina, T. P., \& Sheram, K. (2000). Beyond economic growth: Meeting the challenges of global development. World Bank Publications, World Bank, Washington DC.

Sriram, M. S. (2007). Productivity of Rural Credit: A Review of Issues and Some Recent Literature. International Journal of Rural Management, 3(2), 245-268. http://dx.doi.org/10.1177/097300520800300204

Stampini, M., \& Davis, B. (2008). Does off-farm labor relax farmers' credit constraints? Evidence from longitudinal data for Vietnam. Retrieved from http://papers.ssrn.com/sol3/papers.cfm?abstract_id=1136208

Stiglitz, J., \& Weiss, A. (1981). Credit rationing in markets with imperfect information. American Economic Review, 71, 393-410.

Turvey, C. G., He, G., Jiujie, M. A., Kong, R., \& Meagher, P. (2012). Farm credit and credit demand elasticities in Shaanxi and Gansu. China Economic Review, 23(4), 1020-1035. http://dx.doi.org/10.1016/j.chieco.2012.05.004

Ugbajah, M. O. (2011). Gender Analysis of the Structure and Effects of Access to Financial Services among Rural Farmers in Anambra State, Nigeria. Journal of Agricultural Sciences, 2(2), 107-111.

Ugbajah, M. O. (2014). Provision of Credit and Loan Facilities by Nigerian Agricultural Cooperative and Rural Development Bank (NACRDB) to Farmers: Implications for Extension Services Delivery. Greener Journal of Agricultural Sciences, 4(5), 199-204. http://dx.doi.org/10.15580/GJAS.2014.5.011014028

Villanueva, J. P. B. (2014). Impact of institutional credit to agricultural output in the Philippines: A Cobb-Douglas production function empirical analysis (Doctoral dissertation, Saint Louis University).

Weber, R., \& Musshoff, O. (2012). Is agricultural microcredit really more risky? Evidence from Tanzania. Agricultural Finance Review, 72(3), 416-435. http://dx.doi.org/10.1108/00021461211277268

Weber, R., Mußhoff, O., \& Petrick, M. (2014). How flexible repayment schedules affect credit risk in agricultural microfinance. Working paper no. 1404, University of Goettingen.

Wongnaa, C. A., \& Awunyo-Vitor, D. (2013). Factors affecting loan repayment performance among Yamfarmers in the Sene district, Ghana. Agris on-line Papers in Economics and Informatic, 5(2), 111-122.

Xi, Z., \& Li, Z. N. (2007). Heterogeneous impact of farmer credit: An empirical investigation based on IVQR $\begin{array}{lllll}\text { model. Systems } \quad \text { Engineering-Theory } \quad \& \quad \text { Practice, } & \text { 27(2), }\end{array}$ http://dx.doi.org/10.1016/S1874-8651(08)60011-3

Yuan, Y., Hu, Y., \& Gao, P. (2011). Farmers' choice and informal credit markets in China. Paper presented at the Agricultural \& Applied Economics Association's 2011 AAEA \& NAREA Joint Annual Meeting, Pittsburgh, Pennsylvania, July 24-26, 2011.

Zuberi, H. A. (1989). Production function, institutional credit and agricultural development in Pakistan. The Pakistan Development Review, 28(1), 43-56. 
Table 1. Year-wise classification of reviewed studies

\begin{tabular}{ccc}
\hline Sr. No. & Year & No. of publication \\
\hline 1 & 1995 & 01 \\
2 & 1996 & 01 \\
3 & 1997 & 02 \\
4 & 1998 & 01 \\
5 & 1999 & 02 \\
6 & 2000 & 01 \\
7 & 2001 & 03 \\
8 & 2002 & 01 \\
9 & 2003 & 03 \\
10 & 2004 & 02 \\
11 & 2005 & 02 \\
12 & 2006 & 01 \\
13 & 2007 & 04 \\
14 & 2008 & 06 \\
15 & 2009 & 08 \\
16 & 2010 & 09 \\
17 & 2011 & 12 \\
18 & 2012 & 19 \\
19 & 2013 & 16 \\
20 & 2014 & 14 \\
21 & 2015 & 02 \\
Total & & 110 \\
Maximum & & 16 \\
Minimum & & 01 \\
\hline
\end{tabular}

Source: Based on author's own calculation of reviewed studies.

Table 2. Country-wise classification of studies

\begin{tabular}{lcc}
\hline Country & No. of Publications & Percentage \\
\hline India & 36 & 33 \\
Nigeria & 20 & 18 \\
Pakistan & 09 & 08 \\
China & 05 & 05 \\
Ghana & 05 & 05 \\
Cross country & 05 & 05 \\
South Africa & 04 & 04 \\
Vietnam & 03 & 03 \\
Others & 23 & 21 \\
\hline
\end{tabular}

Note. Others include Indonesia, Ethiopia, Uganda, Iran, Malawi, Thailand, Algeria, Kenya, Peru, Mali, Mexico, Malaysia, Madagascar, Philippines, Cameroon, Yemen, Barbados and Nepal.

Source: Based on author's calculation of reviewed studies given in Table A. 
Table 3. Classification of studies based on source of publication

\begin{tabular}{|c|c|}
\hline Particulars & No. of papers \\
\hline Agricultural Economics Research Review & 9 \\
\hline Journal of Development Economics & 6 \\
\hline Economic and Political Weekly & 5 \\
\hline African Journal of Agricultural Research & 3 \\
\hline SSRN & 3 \\
\hline The Journal of Rural and Agricultural Research & 3 \\
\hline Journal of Social Sciences & 2 \\
\hline China Economic Review & 2 \\
\hline International Journal of Current Research and Academic Review & 2 \\
\hline Sarhad Journal of Agriculture & 2 \\
\hline World Development & 2 \\
\hline Food Policy & 2 \\
\hline Bulletin of Agricultural and Fisheries Economics & 1 \\
\hline Agricultural and Food Economics & 1 \\
\hline Bangladesh e-Journal of Sociology & 1 \\
\hline Food security & 1 \\
\hline Journal of Development and Agricultural Economics & 1 \\
\hline The Journal of Development Studies & 1 \\
\hline International Journal of Food and Agricultural Economics & 1 \\
\hline Theoretical and Applied Economics & 1 \\
\hline Journal of Sustainable Development in Africa & 1 \\
\hline Greener Journal of Agricultural Sciences & 1 \\
\hline Applied Economics & 1 \\
\hline Journal of Agricultural Sciences & 1 \\
\hline African Development Review & 1 \\
\hline American Journal of Experimental Agriculture & 1 \\
\hline MPRA & 1 \\
\hline International Journal of Learning and Development & 1 \\
\hline Journal of Agriculture and Social Sciences & 1 \\
\hline International Journal of Business, Humanities and Technology & 1 \\
\hline European Journal of Business and Management & 1 \\
\hline International Business and Economics Research Journal & 1 \\
\hline International Journal of Scientific and Research Publications & 1 \\
\hline Journal of Management and Information Technology & 1 \\
\hline International Journal of Rural Management & 1 \\
\hline Journal of Rural Development & 1 \\
\hline Asian Journal of Agriculture and Rural Development & 1 \\
\hline Journal of Economic Behavior and Organization & 1 \\
\hline Global Journal of Applied Management and Social Sciences & 1 \\
\hline International Journal of Economics and Finance & 1 \\
\hline American International Journal of Social Science & 1 \\
\hline Journal of Agriculture, Biotechnology and Ecology & 1 \\
\hline Journal of Biology, Agriculture and Healthcare & 1 \\
\hline Agricultural Journal & 1 \\
\hline International Journal of Agriculture and Forestry & 1 \\
\hline The Pakistan Development Review & 1 \\
\hline Agricultural Finance Review & 1 \\
\hline Research Journal of Finance and Accounting & 1 \\
\hline The Journal of Finance & 1 \\
\hline International Journal of Management and Social Sciences Research & 1 \\
\hline Asian Social Science & 1 \\
\hline International Business and Economics Research Journal & 1 \\
\hline Journal of Agriculture and Rural Development in the Tropics and Subtropics & 1 \\
\hline Agricultural Economics & 1 \\
\hline Global Journal of Science Frontier Research & 1 \\
\hline Pakistan Journal of Agricultural Sciences & 1 \\
\hline Journal of Environmental Science, Computer Science and Engineering and Technology & 1 \\
\hline Scholars Journal of Arts, Humanities and Social Sciences & 1 \\
\hline Agris on-line Papers in Economics and Informatics & 1 \\
\hline Conference papers & 7 \\
\hline Working papers and others ${ }^{\mathrm{a}}$ & 16 \\
\hline Total & 110 \\
\hline
\end{tabular}

Note. ${ }^{\text {a }}$ others include working papers, thesis, various reports and surveys available on internet web sites

Source: Based on Table A1. 
Table 4. Distribution of studies based on type of research

\begin{tabular}{lcc}
\hline Methodology & No. of papers & Percentage \\
\hline Exploratory cross sectional & 61 & 56 \\
Empirical & 22 & 20 \\
Descriptive & 19 & 17 \\
Conceptual & 08 & 07 \\
\hline Total & 110 & \\
\hline
\end{tabular}

Source: Based on Table A1.

Table 5. Focus area of literature

\begin{tabular}{lcc}
\hline Focus area & No. of papers & Percentage \\
\hline (a) determinants of sources and amount of agricultural credit & 26 & 24 \\
(b) gender issues in agriculture credit & 04 & 04 \\
(c) status and performance of agricultural credit & 24 & 22 \\
(d) impact of credit on productivity and development & 23 & 21 \\
(e) rationing in credit markets & 12 & 11 \\
(f) repayment issues in agricultural credit & 08 & 07 \\
(g) role of micro-finance in agricultural credit & 06 & 05 \\
(h) agricultural credit pre and post reforms & 05 & 05 \\
(i) credit via Islamic banking & 02 & 02 \\
Total & 110 & \\
\hline
\end{tabular}

Source: Based on author's own calculation based on studies reviewed.

Table 6. Classification based on determinants of agriculture credit

\begin{tabular}{ll}
\hline Type of classification & Variables used \\
\hline Individual factors & Education, marital status, caste, gender, \\
& extension contact, experience, age, size of household, \\
& social status, affiliation to political party, \\
& membership of farmer's association \\
& Income level, collateral value, rate of interest, \\
& transaction cost, total cost of production, \\
Economic factors & land size, incidence of past savings, \\
& participation in off-farm activities, \\
& value of livestock, healthcare expenditure, \\
& expenses on child education, \\
& repayment capacity, net margins \\
Irrigation facilities, & access to basic infrastructure facilities, \\
purpose and duration of loan, type of crop, & distance from lending institution, \\
& status of land records \\
\hline
\end{tabular}

Note. Based on exploratory cross- sectional studies only.

Source: Based on author's review of studies.

Table 7. Classification of studies according to techniques used

\begin{tabular}{lcc}
\hline Techniques used & No. of studies & Percentage \\
\hline Logit Analysis & 10 & 38 \\
Probit Analysis & 05 & 19 \\
ANOVA & 02 & 08 \\
Regression & 04 & 15 \\
Others & 05 & 20 \\
\hline
\end{tabular}

Note. Others include Tobit analysis, discriminant analysis, general linear model, ratio analysis, mixed approaches.

Source: Based on author's own calculation of reviewed studies. 
Table 8. Distribution of studies based on methodology used to study impact of credit on output

\begin{tabular}{lcc}
\hline Approach used & No. of Studies & Percentage \\
\hline Cob-Douglas production function & 11 & 37 \\
Granger causality and co integration & 08 & 27 \\
Regression & 06 & 20 \\
Others* & 05 & 16 \\
\hline
\end{tabular}

Note. others include probit modeling, simultaneous equation modeling and mixed approaches.

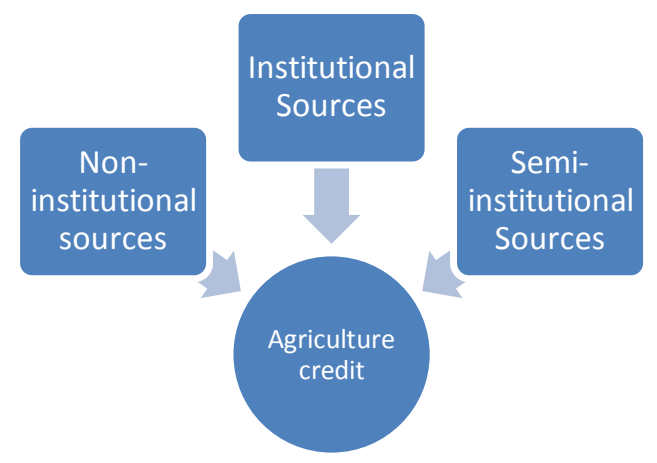

Figure 1. Sources of agriculture credit

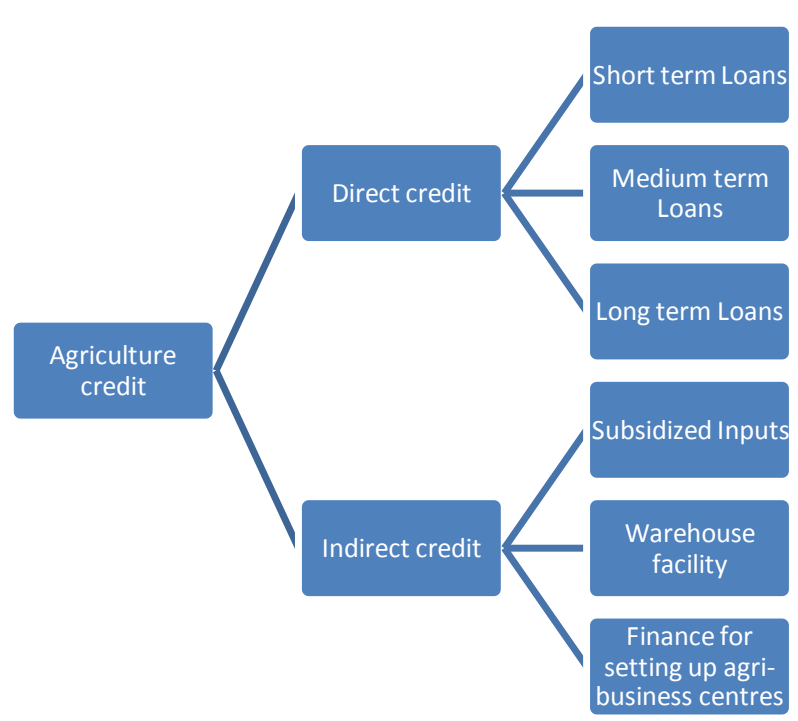

Figure 2. Components of direct and indirect agriculture credit

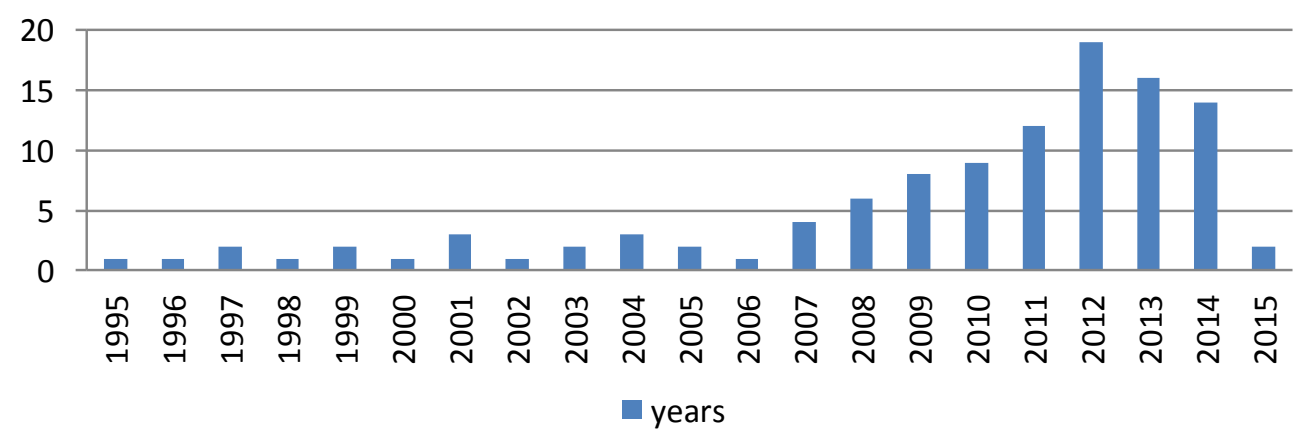

Figure 3. Year wise classification of reviewed studies 


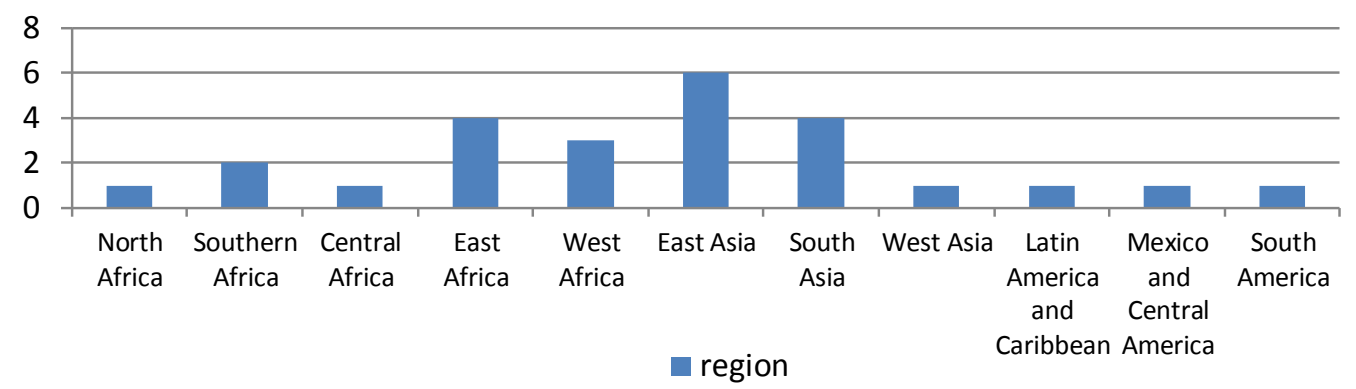

Figure 4. Region-wise classification of studies

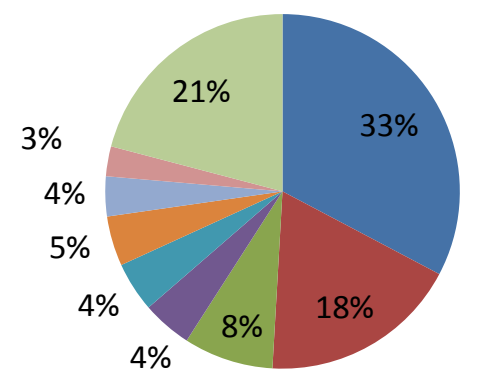

$$
\begin{aligned}
& \text { - India } \\
& \text { - Nigeria } \\
& \text { - Pakistan } \\
& \text { - China } \\
& \text { - Ghana } \\
& \text { - Cross country } \\
& \text { - South Africa } \\
& \text { - Vietnam } \\
& \text { Others }
\end{aligned}
$$

Figure 5. Country wise publication of studies

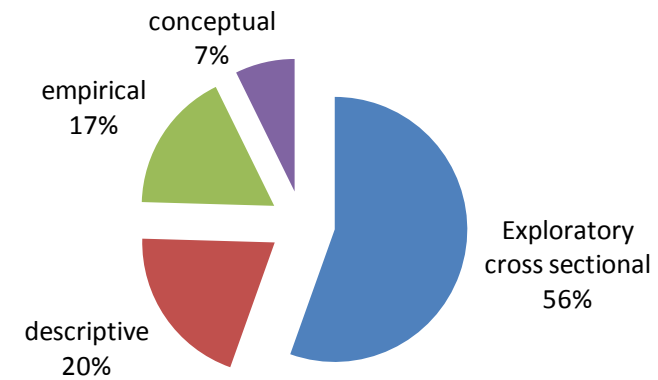

Figure 6. Distribution of studies based on type of research
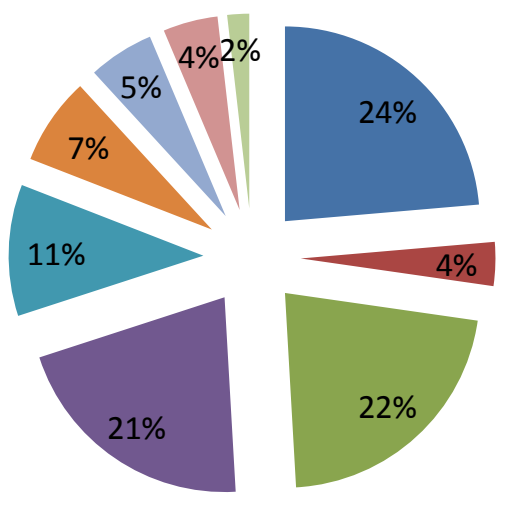
- (a) determinants of agricultural credit
(b) gender issues
(c) status and performance
(d) impact on productivity
(e) rationing in credit
(f) repayment issues
(g) credit via MFI
(h) credit pre and post reforms
(i) role of islamic banking

Figure 7. Focus area of literature 


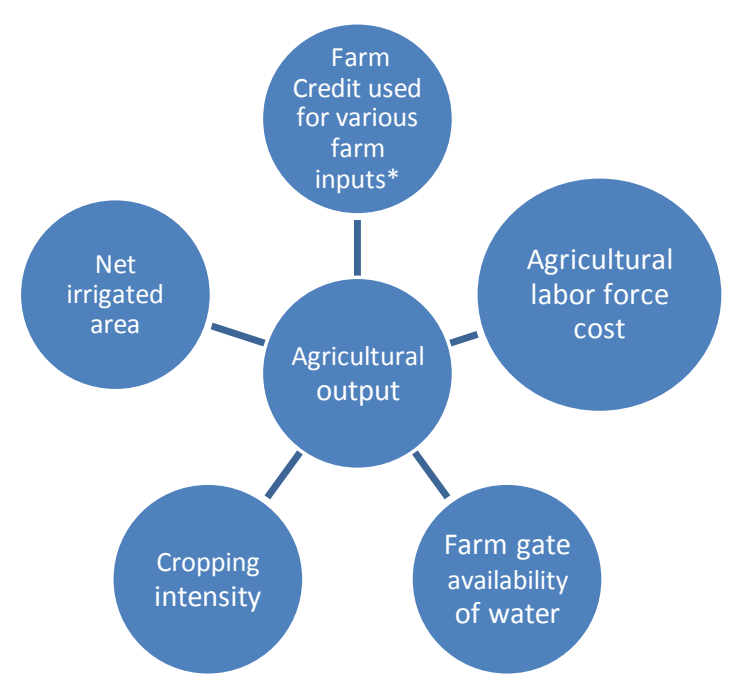

Figure 8. Classification of various input variables used in various production functions

Note 1. * means credit used for various inputs like seed, implementation of machinery and tube well, fertilizers, pesticides \& fungicides, land preparation other costs.

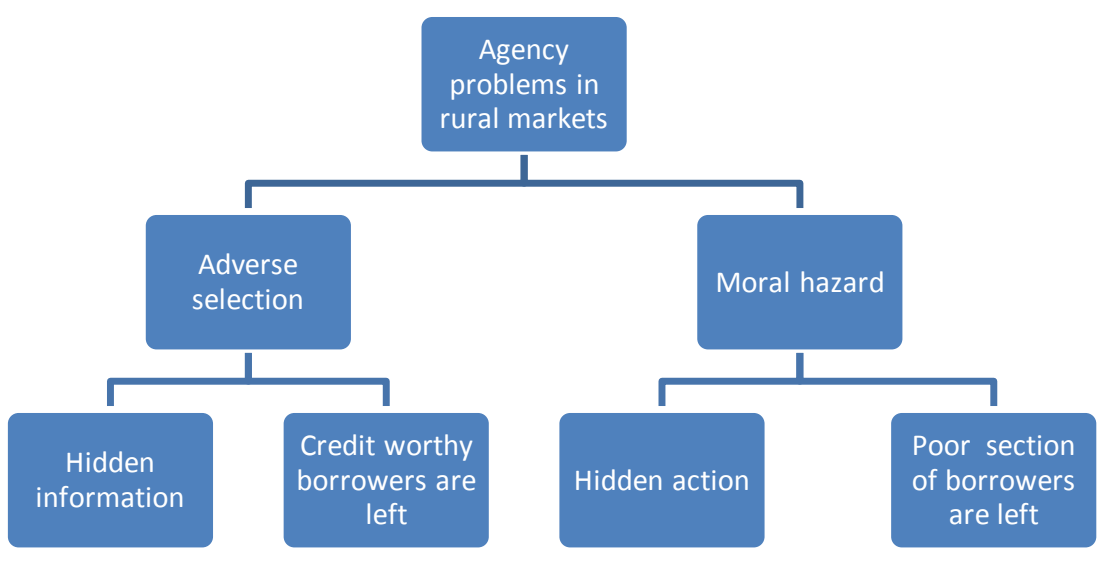

Figure 9. Agency problems in rural markets

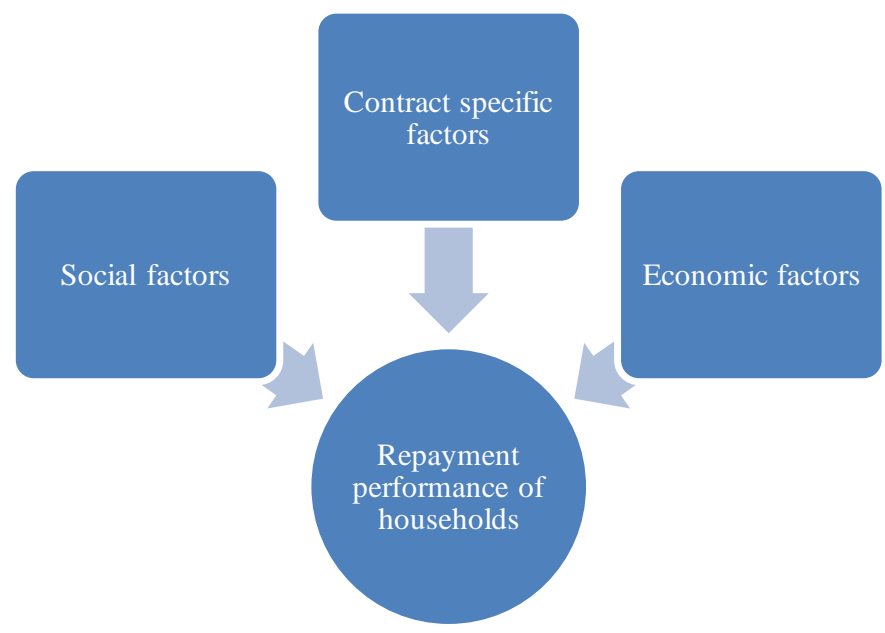

Figure 10. Factors affecting repayment performance of households 
Table A1. Comprehensive snapshot of classification of 110 reviewed studies

\begin{tabular}{|c|c|c|c|c|}
\hline \multicolumn{2}{|c|}{ Sr. no.Author (year) } & $\begin{array}{l}\text { Focus } \\
\text { area }\end{array}$ & methodology & findings \\
\hline \multicolumn{2}{|r|}{1 Aliero \& Ibrahim (2011) (Nigeria) } & 1 & $\begin{array}{l}\text { exploratory } \\
\text { Cross sectional }\end{array}$ & $\begin{array}{l}\text { Income level, collateral, education, marital status have } \\
\text { significant positive impact on farmer's access to credit while rate of interest } \\
\text { and transaction costs impact it negatively }\end{array}$ \\
\hline \multicolumn{2}{|r|}{ Datta \& Ghosh (2013) (India) } & 1 & $\begin{array}{l}\text { Exploratory } \\
\text { Cross sectional }\end{array}$ & $\begin{array}{l}\text { Borrowers of formal sector have better access to electricity and irrigation } \\
\text { facilities, belong to upper caste and have better access to infrastructure } \\
\text { facilities }\end{array}$ \\
\hline \multicolumn{2}{|r|}{ Reddy (2012) (India) } & 1 & $\begin{array}{l}\text { exploratory } \\
\text { Cross sectional }\end{array}$ & $\begin{array}{l}\text { Borrowings from formal sector are for longer duration and for } \\
\text { productive purposes. }\end{array}$ \\
\hline \multicolumn{2}{|r|}{$\begin{array}{l}\text { Gandhimathi \& Vanitha (2010) } \\
\text { India) }\end{array}$} & 1 & exploratory & Cost of production and land size major factors in \\
\hline \multicolumn{2}{|r|}{5 Pal \& Laha (2014) (India) } & 1 & $\begin{array}{l}\text { Cross sectional } \\
\text { exploratory } \\
\text { Cross sectional }\end{array}$ & $\begin{array}{l}\text { discriminating borrowers of cooperative and commercial banks } \\
\text { Institutional credit skewed towards resource-rich households }\end{array}$ \\
\hline \multicolumn{2}{|r|}{6 Hussain \& Thapa (2012) (Pakistan) } & 1 & $\begin{array}{l}\text { exploratory } \\
\text { Cross sectional }\end{array}$ & $\begin{array}{l}\text { Lengthy process of loan sanctioning and arbitrary assessment of } \\
\text { collateral value constraint access to institutional credit by smallholders }\end{array}$ \\
\hline \multicolumn{2}{|r|}{7 Nouman et al. (2013) (Pakistan) } & 1 & $\begin{array}{l}\text { exploratory } \\
\text { Cross sectional }\end{array}$ & $\begin{array}{l}\text { Farm status, farm size, literacy level and marital status significantly } \\
\text { affect amount of agricultural credit. }\end{array}$ \\
\hline \multicolumn{2}{|r|}{8 Dzadze et al. (2012) (Ghana) } & 1 & $\begin{array}{l}\text { exploratory } \\
\text { Cross sectional }\end{array}$ & $\begin{array}{l}\text { access to agricultural credit is positively and significantly affected by } \\
\text { level of education, extension contact and habit of saving. }\end{array}$ \\
\hline \multicolumn{2}{|r|}{9 Bashiru et al. (2014) (Ghana) } & 1 & $\begin{array}{l}\text { exploratory } \\
\text { Cross sectional }\end{array}$ & $\begin{array}{l}\text { Average amount of credit availed by farmers is same across all sources } \\
\text { of credit and that credit used for both productive and non-productive } \\
\text { purposes in study area }\end{array}$ \\
\hline \multirow{2}{*}{\multicolumn{2}{|c|}{$\begin{array}{l}10 \text { Sebopetji \& Belete (2009) (So } \\
\text { Africa) }\end{array}$}} & 1 & exploratory & Years of experience, gender and marital status positively affect \\
\hline & & & Cross sectional & $\begin{array}{l}\text { farmer household's decision to use credit while age, literacy level } \\
\text { and farmer association's membership affect it negatively. }\end{array}$ \\
\hline \multirow{2}{*}{\multicolumn{2}{|c|}{$\begin{array}{l}11 \text { Stampini \& Davis (2008) } \\
\text { (Vietnam) }\end{array}$}} & 1 & empirical & Participation in non-farm labor activities relaxes credit constraints \\
\hline & & & & and increases spending on farm inputs. \\
\hline \multicolumn{2}{|r|}{12 Admasu \& Paul (2010) (Ethiopia) } & 1 & $\begin{array}{l}\text { exploratory } \\
\text { Cross sectional }\end{array}$ & $\begin{array}{l}\text { Working land size is crucial to decide quantum of input loan } \\
\text { sanctioned by cooperatives. }\end{array}$ \\
\hline \multicolumn{2}{|r|}{13 Ugbajah (2014) (Nigeria) } & 1 & $\begin{array}{l}\text { exploratory } \\
\text { Cross sectional }\end{array}$ & $\begin{array}{l}\text { Late release of funds and short payback period are major problems } \\
\text { faced by beneficiaries. }\end{array}$ \\
\hline & Mpuga (2010) (Uganda) & 1 & $\begin{array}{l}\text { exploratory } \\
\text { Cross sectional }\end{array}$ & $\begin{array}{l}\text { Young and educated people are more likely to get required } \\
\text { institutional credit }\end{array}$ \\
\hline \multicolumn{2}{|r|}{5 Diagne \& Zeller (2001) (Malawi) } & 1 & $\begin{array}{l}\text { exploratory } \\
\text { Cross sectional }\end{array}$ & $\begin{array}{l}\text { Higher size of landholding and livestock are negatively correlated with } \\
\text { access to formal credit. }\end{array}$ \\
\hline \multicolumn{2}{|r|}{6 Gine \& Yang (2009) (Malawi) } & 1 & $\begin{array}{l}\text { exploratory } \\
\text { Cross sectional }\end{array}$ & $\begin{array}{l}\text { Bundling an insurance scheme with crop loan increases effective } \\
\text { interest rate on loan and thereby suppress the demand for loan }\end{array}$ \\
\hline \multicolumn{2}{|r|}{$\begin{array}{l}17 \text { Salami \& Arawomo (2013) } \\
\text { (Cross country) }\end{array}$} & 1 & empirical & Incidence of higher rate of savings initiates higher farm credit \\
\hline & Akpan et al. (2013) (Nigeria) & 1 & $\begin{array}{l}\text { exploratory } \\
\text { cross sectional }\end{array}$ & $\begin{array}{l}\text { Age, gender, land size, visit by extension agents, distance, literacy level } \\
\text { organizational membership, size of household and distance significantly } \\
\text { affect access to credit }\end{array}$ \\
\hline 19 & Munyambonera (2014) (Uganda) & 1 & $\begin{array}{l}\text { exploratory } \\
\text { Cross sectional }\end{array}$ & $\begin{array}{l}\text { Informal sector caters to majority of needs of rural communities } \\
\text { in Uganda }\end{array}$ \\
\hline 20 & Sharma et al. (2012) (India) & 1 & $\begin{array}{l}\text { exploratory } \\
\text { Cross sectional }\end{array}$ & $\begin{array}{l}\text { Dearth of financial institutions is the principal demand side constraint } \\
\text { while inadequate staff and dominance of large farmers are principal } \\
\text { supply side constraints to credit }\end{array}$ \\
\hline & Turvey et al. (2012) (China) & 1 & $\begin{array}{l}\text { exploratory } \\
\text { Cross sectional }\end{array}$ & Demand for credit is not highly inelastic for all households \\
\hline & Das (2015) (India) & 1 & $\begin{array}{l}\text { exploratory } \\
\text { Cross sectional }\end{array}$ & $\begin{array}{l}\text { Expenses on children education, occupation, family size } \\
\text { land size are significant determinants of agricultural credit }\end{array}$ \\
\hline
\end{tabular}




\begin{tabular}{|c|c|c|c|c|}
\hline 23 & Akudugu (2012) (Ghana) & 1 & $\begin{array}{l}\text { exploratory } \\
\text { Cross sectional }\end{array}$ & $\begin{array}{l}\text { Age, gender, affiliation to political party are demand side while } \\
\text { type of crop, land size and incidence of savings are supply side determinants } \\
\text { of amount of credit }\end{array}$ \\
\hline 24 & Yuan et al. (2011) (China) & 1 & $\begin{array}{l}\text { exploratory } \\
\text { Cross sectional }\end{array}$ & $\begin{array}{l}\text { the incidence of high savings and income lower down credit } \\
\text { constraints }\end{array}$ \\
\hline & $\begin{array}{l}\text { Baiyegunhi \& Fraser (2014) } \\
\text { outh Africa) }\end{array}$ & 1 & exploratory & Gender, education, asset value, repayment capacity of borrower, social \\
\hline & $\begin{array}{l}\text { Ololade \& Olagunju } \quad \text { (2013) } \\
\text { igeria) }\end{array}$ & 1 & $\begin{array}{l}\text { Cross sectional } \\
\text { exploratory }\end{array}$ & $\begin{array}{l}\text { capital and income affect household's demand for credit } \\
\text { Gender, marital status, interest rate and presence of guarantor significantly }\end{array}$ \\
\hline 27 & Ugbajah (2011) (Nigeria) & 2 & $\begin{array}{l}\text { Cross sectional } \\
\text { exploratory } \\
\text { Cross sectional }\end{array}$ & $\begin{array}{l}\text { affect household's access to credit } \\
\text { Males have better access to formal financial services than females. }\end{array}$ \\
\hline 28 & Jeiyol et al. (2013) (Nigeria) & 2 & $\begin{array}{l}\text { exploratory } \\
\text { Cross sectional }\end{array}$ & Factors constraining credit are different for males and females \\
\hline 29 & Chavan (2008) (India) & 2 & descriptive & $\begin{array}{l}\text { The share of women in terms of both number of accounts and amount } \\
\text { of loans is lesser as compared to male borrowers }\end{array}$ \\
\hline 30 & Akudugu et al. (2009) (Ghana) & 2 & $\begin{array}{l}\text { exploratory } \\
\text { Cross sectional }\end{array}$ & $\begin{array}{l}\text { Years of schooling, annual income, application procedures, land size, } \\
\text { savings, type of crop, rate of interest and distance from rural banks } \\
\text { significantly affect women farmer's access to credit }\end{array}$ \\
\hline & $\begin{array}{l}\text { Jumrani \& Agarwal (2012) } \\
\text { dia) }\end{array}$ & 3 & descriptive & $\begin{array}{l}\text { The gap between small and large landholders in terms of amount } \\
\text { outstanding per account is widening. }\end{array}$ \\
\hline 32 & Satyasai (2008) (India) & 3 & descriptive & $\begin{array}{l}\text { The multiagency approach to credit delivery in rural India has turned } \\
\text { out to be ineffective }\end{array}$ \\
\hline 33 & Ayegba \& Ikani (2013) (Nigeria) & 3 & $\begin{array}{l}\text { exploratory } \\
\text { Cross sectional }\end{array}$ & $\begin{array}{l}\text { High interest rate and inadequate credit are major challenges in access } \\
\text { to formal credit, thereby making private moneylenders a primary source of } \\
\text { credit }\end{array}$ \\
\hline 34 & Mandal et al. (2005) (India) & 3 & $\begin{array}{l}\text { exploratory } \\
\text { Cross sectional }\end{array}$ & $\begin{array}{l}\text { Farmers constrained by insufficient capital to invest in farm } \\
\text { operations }\end{array}$ \\
\hline 35 & Bista et al. (2012) (India) & 3 & empirical & $\begin{array}{l}\text { Net margins on total output higher for beneficiary of Kisan Credit Cards } \\
\text { than non-beneficiary }\end{array}$ \\
\hline 36 & Singh et al. (2009) (India) & 3 & $\begin{array}{l}\text { exploratory } \\
\text { Cross sectional }\end{array}$ & $\begin{array}{l}\text { Transaction costs higher for obtaining credit from institutional sources } \\
\text { than non-institutional sources }\end{array}$ \\
\hline 37 & Konare (2001) (Mali) & 3 & empirical & Shortage of development investment finance with rural households \\
\hline 38 & Satyasai (2012) (India) & 3 & empirical & Higher credit use associated with increased use of input in production \\
\hline 39 & Pradhan (2013) (India) & 3 & descriptive & $\begin{array}{l}\text { institutional credit is restricted to less risky activities, informal credit } \\
\text { used for non-productive purposes while role of micro-finance is dubious }\end{array}$ \\
\hline 40 & Golait (2007) (India) & 3 & descriptive & Credit delivery to small and marginal holders is inadequate \\
\hline 41 & Badiru (2010) (Nigeria) & 3 & descriptive & $\begin{array}{l}\text { High incidence of repayment for loans from informal and semi-formal } \\
\text { Sources of finance }\end{array}$ \\
\hline 42 & Joshi \& Gautam (2014) (India) & 3 & descriptive & Presence of regional disparities in disbursement of credit \\
\hline 43 & Bashir et al. (2013) (India) & 3 & descriptive & $\begin{array}{l}\text { Highest increase in total loans issued by scheduled commercial banks } \\
\text { while lowest was for cooperatives during study period }\end{array}$ \\
\hline 44 & Devaraja (2011) (India) & 3 & descriptive & $\begin{array}{l}\text { Flow of credit to small and marginal farmers is inadequate in relation to its } \\
\text { demand }\end{array}$ \\
\hline 45 & Shukla \& Tewari (2012) (India) & 3 & descriptive & $\begin{array}{l}\text { Direct finance to agriculture increased for small and marginal holders } \\
\text { during pre and post liberalization period }\end{array}$ \\
\hline 46 & Singh \& Kant (2014) (India) & 3 & $\begin{array}{l}\text { exploratory } \\
\text { Cross sectional }\end{array}$ & Institutional credit is utilized mostly for productive purposes \\
\hline $\begin{array}{l}47 \\
\text { Afri }\end{array}$ & $\begin{array}{l}\text { Chisasa \& Makina (2012) (South } \\
\text { ica) }\end{array}$ & 3 & descriptive & $\begin{array}{l}\text { Commercial banks prefer lending to large farmers than small farmers due to } \\
\text { lack of collateral }\end{array}$ \\
\hline & $\begin{array}{l}\text { Ramakumar \& Chavan (2007) } \\
\text { dia) }\end{array}$ & 3 & descriptive & $\begin{array}{l}\text { Agri-business oriented units capture significant proportion of direct finance } \\
\text { as compared to small and marginal landholders. }\end{array}$ \\
\hline 49 & Mohan (2006) (India) & 3 & descriptive & Gaps in the flow of agriculture credit via institutional setup in India. \\
\hline 50 & Jan et al. (2012) (Pakistan) & 3 & $\begin{array}{l}\text { Exploratory } \\
\text { Cross sectional }\end{array}$ & $\begin{array}{l}\text { Non-upgraded land records, lack of collateral, cumbersome loan procedure, } \\
\text { rigid repayment schedules are responsible for not preferring formal credit. }\end{array}$ \\
\hline
\end{tabular}




\begin{tabular}{|c|c|c|c|c|}
\hline 51 & Gulati \& Bathla (2002) (India) & 3 & descriptive & High incidence of bad debts in most of the rural finance institutions. \\
\hline 52 & Olowa \& Olowa (2011) (Nigeria) & 3 & conceptual & $\begin{array}{l}\text { Ineffective agricultural credit policies and their inadequate monitoring } \\
\text { and evaluation make institutional credit ineffective }\end{array}$ \\
\hline & $\begin{array}{l}\text { Satyasai \& Badatya (2000) } \\
\text { lia) }\end{array}$ & 3 & descriptive & Inter-state variation in disbursement of credit \\
\hline 54 & Kumar \& Singh (2010) (India) & 3 & empirical & $\begin{array}{l}\text { Share of institutional credit to total credit has declined } \\
\text { over past four decades. }\end{array}$ \\
\hline 55 & Binam et al. (2004) (Cameroon) & 4 & exploratory & Credit is an important determinant of technical efficiency of farmers \\
\hline & $\begin{array}{l}\text { De Rosari et al. (2014) } \\
\text { lonesia) }\end{array}$ & 4 & $\begin{array}{l}\text { Cross sectional } \\
\text { exploratory }\end{array}$ & Use of credit and capital supports significantly impact production, \\
\hline & $\begin{array}{l}\text { Kumar et al. (2012) (India and } \\
\text { na) }\end{array}$ & 4 & $\begin{array}{l}\text { Cross sectional } \\
\text { exploratory }\end{array}$ & $\begin{array}{l}\text { consumption and investment behavior of farmers. } \\
\text { Constraining credit has more severe impact on productivity in India than } \\
\text { China }\end{array}$ \\
\hline 58 & Ahmad (2011) (Pakistan) & 4 & empirical & Indirect credit has significant positive impact on agricultural output. \\
\hline 59 & Sjah et al. (2003) (Indonesia) & 4 & $\begin{array}{l}\text { exploratory } \\
\text { Cross sectional }\end{array}$ & $\begin{array}{l}\text { agricultural credit has little impact on agricultural production and } \\
\text { farmer's income }\end{array}$ \\
\hline & $\begin{array}{l}\text { Bolarinwa \& Fakoya }(2011) \\
\text { geria) }\end{array}$ & 4 & $\begin{array}{l}\text { Exploratory } \\
\text { Cross sectional }\end{array}$ & Agricultural credit is positively correlated with farm production \\
\hline 61 & Obilor (2013) (Nigeria) & 4 & empirical & $\begin{array}{l}\text { Agricultural credit guarantee loan has significant positive impact on } \\
\text { agricultural productivity. }\end{array}$ \\
\hline 62 & Saleem \& Jan (2011) (Pakistan) & 4 & empirical & Increased use of credit increases agricultural GDP in Pakistan \\
\hline 63 & Dong et al. (2010) (China) & 4 & exploratory & Constrained access to credit decreases the overall farm productivity \\
\hline 64 & Kishore (2012) (India) & 4 & $\begin{array}{l}\text { Cross sectional } \\
\text { descriptive }\end{array}$ & $\begin{array}{l}\text { Commercialization of Indian agriculture has made it less profitable for } \\
\text { the farmers. }\end{array}$ \\
\hline 65 & Sriram (2007) (India) & 4 & $\begin{array}{l}\text { Exploratory } \\
\text { Cross sectional }\end{array}$ & $\begin{array}{l}\text { Causality between agricultural credit and output cannot be directly } \\
\text { established }\end{array}$ \\
\hline 66 & Owuor \& Shem (2012) (Kenya ) & 4 & $\begin{array}{l}\text { Exploratory } \\
\text { Cross sectional }\end{array}$ & Participation in group based lending significantly impacts output \\
\hline 67 & Das et al. (2009) (India) & 4 & empirical & $\begin{array}{l}\text { Direct agricultural credit has immediate positive effect on productivity } \\
\text { while indirect credit effects productivity with an year lag }\end{array}$ \\
\hline 68 & Okulegu et al. (2014) (Nigeria) & 4 & empirical & $\begin{array}{l}\text { Long-run relationship between agricultural GDP and commercial bank } \\
\text { credit to agriculture sector }\end{array}$ \\
\hline 69 & Sial et al. (2011) (Pakistan) & 4 & empirical & Agricultural credit has positive and significant impact on GDP \\
\hline 70 & Fakayode et al. (2009) (Nigeria) & 4 & $\begin{array}{l}\text { exploratory } \\
\text { cross sectional }\end{array}$ & $\begin{array}{l}\text { Credit along with other factor inputs is an important determinant of } \\
\text { agricultural output }\end{array}$ \\
\hline & $\begin{array}{l}\text { Olagunju \& Adeyemo (2007) } \\
\text { geria) }\end{array}$ & 4 & $\begin{array}{l}\text { Exploratory } \\
\text { Cross sectional }\end{array}$ & $\begin{array}{l}\text { After merging beneficiaries more technically efficient than their before } \\
\text { merging counterparts }\end{array}$ \\
\hline 72 & Ammani (2012) (Nigeria) & 4 & empirical & $\begin{array}{l}\text { Agriculture credit positively related to crop production, fishing and } \\
\text { livestock sector }\end{array}$ \\
\hline 73 & Iqbal et al. (2003) (Pakistan) & 4 & empirical & $\begin{array}{l}\text { Positive significant relationship between institutional credit and agricultural } \\
\text { GDP }\end{array}$ \\
\hline 74 & Bruhn \& Love (2014) (Mexico) & 4 & $\begin{array}{l}\text { exploratory } \\
\text { Cross sectional }\end{array}$ & $\begin{array}{l}\text { Increased access to credit has positive effect on labor market } \\
\text { and hence economic decisions of low-income groups }\end{array}$ \\
\hline $\begin{array}{l}75 \\
\mathrm{Afr}\end{array}$ & $\begin{array}{l}\text { Chisasa \& Makina (2013) (South } \\
\text { ica) }\end{array}$ & 4 & empirical & Bank credit has positive significant impact on agricultural output \\
\hline 76 & Bashir et al. (2010) (Pakistan) & 4 & $\begin{array}{l}\text { exploratory } \\
\text { Cross sectional }\end{array}$ & Credit has significant positive impact on total farm output \\
\hline 77 & Rima (2014) (Nepal) & 4 & empirical & $\begin{array}{l}\text { Institutional credit is a significant determinant of improving agricultural } \\
\text { GDP }\end{array}$ \\
\hline & $\begin{array}{l}\text { Nagarajan et } \quad \text { al. } \quad(1995) \\
\text { ilippines ) }\end{array}$ & 5 & $\begin{array}{l}\text { Exploratory } \\
\text { Cross sectional }\end{array}$ & $\begin{array}{l}\text { Occupational specialization determines matching of non-institutional } \\
\text { lenders with borrowers in rural informal credit markets }\end{array}$ \\
\hline 79 & Jain (1999) (Cross country) & 5 & conceptual & Actions in formal sector have bearing on policies of informal sector \\
\hline 80 & Beaman et al. (2014) (Mali) & 5 & $\begin{array}{l}\text { exploratory } \\
\text { Cross sectional }\end{array}$ & $\begin{array}{l}\text { Higher marginal returns to investment leads to self-selection in credit } \\
\text { markets }\end{array}$ \\
\hline
\end{tabular}




\begin{tabular}{|c|c|c|c|c|}
\hline 81 & Guirkinger (2008) (Peru) & 5 & $\begin{array}{l}\text { Exploratory } \\
\text { Cross sectional }\end{array}$ & $\begin{array}{l}\text { Formal lenders employ contractual incentives to avoid risk whereas } \\
\text { informal lenders substitute information-intensive lending for contractual } \\
\text { risk }\end{array}$ \\
\hline 82 & Bose (1998) (cross country) & 5 & conceptual & $\begin{array}{l}\text { Credit rationing in formal sector has an adverse composition effect on } \\
\text { availability of credit in informal sector }\end{array}$ \\
\hline 83 & Kochar (1997) (India) & 5 & conceptual & $\begin{array}{l}\text { Lower demand for formal credit limits its role in enhancing agricultural } \\
\text { development }\end{array}$ \\
\hline 84 & Chaudhuri \& Gupta (1996) (India) & 5 & conceptual & $\begin{array}{l}\text { The policy of agricultural price and subsidizing credit by government } \\
\text { adversely affects interest rate in informal sector }\end{array}$ \\
\hline & $\begin{array}{l}\text { Chakrabarty \& Chaudhari (2001) } \\
\text { lia) }\end{array}$ & 5 & conceptual & $\begin{array}{l}\text { Providing formal credit at subsidized rates and in flexible amounts can } \\
\text { increase efficiency of rural credit markets }\end{array}$ \\
\hline 86 & Basu (1997) (India) & 5 & conceptual & $\begin{array}{l}\text { Remarkable relation between congruence of interest and recognition of } \\
\text { entitlement set. }\end{array}$ \\
\hline 87 & Rui \& Xi (2010) (China) & 5 & $\begin{array}{l}\text { Exploratory } \\
\text { Cross sectional }\end{array}$ & $\begin{array}{l}\text { Demand for credit is positively correlated with land size, education, } \\
\text { healthcare expenses, while negatively correlated with household's liquidity. }\end{array}$ \\
\hline 88 & Li et al. (2013) (China) & 5 & $\begin{array}{l}\text { exploratory } \\
\text { Cross sectional }\end{array}$ & $\begin{array}{l}\text { Credit rationing leads to significant welfare loss measured in terms of } \\
\text { net income and consumption of households. }\end{array}$ \\
\hline 89 & Barslund \& Tarp (2008) (Vietnam) & 5 & $\begin{array}{l}\text { exploratory } \\
\text { Cross sectional }\end{array}$ & $\begin{array}{l}\text { Formal loans are utilized for production purposes while informal loans } \\
\text { are utilized for consumption purposes. }\end{array}$ \\
\hline & $\begin{array}{l}\text { Kohansal \& Mansoori (2009) } \\
\text { n) }\end{array}$ & 6 & $\begin{array}{l}\text { Exploratory } \\
\text { Cross sectional }\end{array}$ & $\begin{array}{l}\text { Interest rate, experience in farming and total application costs are important } \\
\text { factors affecting loan repayment by farmers. }\end{array}$ \\
\hline 91 & Duy (2013) (Vietnam) & 6 & $\begin{array}{l}\text { exploratory } \\
\text { Cross sectional }\end{array}$ & $\begin{array}{l}\text { Repayment performance of farmers is higher as compared to } \\
\text { non-farmers. }\end{array}$ \\
\hline 92 & Idoge (2013) (Nigeria) & 6 & $\begin{array}{l}\text { exploratory } \\
\text { Cross sectional }\end{array}$ & $\begin{array}{l}\text { Age, literacy level, loan amount, net income from farm, farm size, side } \\
\text { job, effective supervision have positive impact on repayment while } \\
\text { gender, marital status and household size impact it negatively }\end{array}$ \\
\hline 93 & Weber et al. (2014) (Madagaskar) & 6 & $\begin{array}{l}\text { exploratory } \\
\text { Cross sectional }\end{array}$ & Delinquency of seasonal and non-seasonal farmers are same \\
\hline \multirow{2}{*}{\multicolumn{2}{|c|}{$\begin{array}{l}94 \text { Wongnaa \& Awunyo-vitor (2013) } \\
\text { (Ghana) }\end{array}$}} & 6 & exploratory & Education, experience, age, net margin, income from other sources and \\
\hline & & & Cross sectional & $\begin{array}{l}\text { effective supervision are positively associated with repayment while } \\
\text { gender and marital status affect it negatively }\end{array}$ \\
\hline 95 & Afolabi (2010) (Nigeria) & 6 & $\begin{array}{l}\text { exploratory } \\
\text { cross sectional }\end{array}$ & $\begin{array}{l}\text { Loan amount, years of experience in farming, size of landholding, farm } \\
\text { income, income from other sources and rate of interest charged on } \\
\text { loan significantly affect loan repayment by farmer households }\end{array}$ \\
\hline 96 & Augwumba et al. (2014) (Nigeria) & 6 & $\begin{array}{l}\text { exploratory } \\
\text { Cross sectional }\end{array}$ & $\begin{array}{l}\text { Gender and annual income from farming positively influence loan } \\
\text { repayment while family commitments, price fluctuation, incidence of } \\
\text { diseases and pests constrain it }\end{array}$ \\
\hline & $\begin{array}{l}\text { Ojaiko \& Ogbukwa } \quad \text { (2012) } \\
\text { geria) }\end{array}$ & 6 & $\begin{array}{l}\text { Exploratory } \\
\text { Cross sectional }\end{array}$ & Positive influence of loan size and farm size on repayment rate \\
\hline 98 & Miller (2011) (Cross country) & 7 & conceptual & $\begin{array}{l}\text { Management of agricultural risk and investment can be improved with } \\
\text { microfinance }\end{array}$ \\
\hline 99 & Asanoy (2004) (Yemen) & 7 & $\begin{array}{l}\text { exploratory } \\
\text { cross sectional }\end{array}$ & $\begin{array}{l}\text { Income, literacy rate and family size significantly affect preference for } \\
\text { microfinance }\end{array}$ \\
\hline $\begin{array}{l}100 \\
\text { (Indi }\end{array}$ & $\begin{array}{l}\text { Rao \& Priyadarshini (2013) } \\
\text { lia) }\end{array}$ & 7 & descriptive & $\begin{array}{l}\text { Microfinance serves as an important tool to reduce income and } \\
\text { consumption disparities }\end{array}$ \\
\hline 101 & Balogun \& Yusuf (2011) (Nigeria) & 7 & $\begin{array}{l}\text { exploratory } \\
\text { Cross sectional }\end{array}$ & $\begin{array}{l}\text { Social capital variables, credit variables and dependency ratio of } \\
\text { households significantly affect their demand for credit. }\end{array}$ \\
\hline 102 & Coleman (1999) (Thailand) & 7 & $\begin{array}{l}\text { exploratory } \\
\text { Cross sectional }\end{array}$ & $\begin{array}{l}\text { Group lending program loan significantly and positively impact high } \\
\text { interest debt for females }\end{array}$ \\
\hline $\begin{array}{l}103 \\
(\text { Bark }\end{array}$ & $\begin{array}{l}\text { Knight \& Hossain } \quad(2008) \\
\text { bardos) }\end{array}$ & 7 & descriptive & $\begin{array}{l}\text { Small markets, intense competition, poor repayment, over emphasis on } \\
\text { collateral pose constraint to growth of MFIs. }\end{array}$ \\
\hline 104 & Admassie (2004) (Ethiopia) & 8 & descriptive & $\begin{array}{l}\text { Scarcity of deposit facilities in rural areas hamper welfare of small and } \\
\text { marginal farmers. }\end{array}$ \\
\hline 105 & Izhar \& Tariq (2009) (India) & 8 & empirical & $\begin{array}{l}\text { Institutional credit as percentage to agricultural GDP increased enormously } \\
\text { during post reform period }\end{array}$ \\
\hline
\end{tabular}




\begin{tabular}{|c|c|c|c|}
\hline 106 Sahu \& Rajasekhar (2005) (India) & 8 & descriptive & $\begin{array}{l}\text { Incidence of bank branches positively associated with credit supply to } \\
\text { agriculture and share of agriculture credit to net bank credit declined after } \\
\text { banking sector reforms }\end{array}$ \\
\hline 108 Laoubi \& Yamao (2012) (Algeria) & 8 & descriptive & $\begin{array}{l}\text { Various phases of agriculture development have yielded mixed results on } \\
\text { agricultural development }\end{array}$ \\
\hline 109 Shafiai \& Moi (2015) (Malaysia) & 9 & $\begin{array}{l}\text { exploratory } \\
\text { cross sectional }\end{array}$ & $\begin{array}{l}\text { Most households face financial constraint in second cycle cultivation in the } \\
\text { study area }\end{array}$ \\
\hline 110 Hassan et al. (2012) (Pakistan) & 9 & empirical & $\begin{array}{l}\text { Positive relation exists between Islamic banking and agriculture sector in } \\
\text { the study area }\end{array}$ \\
\hline
\end{tabular}

Notes. 1- determinants of agricultural credit; 2- gender issues in agricultural credit; 3- status and performance of agriculture credit; 4- credit and productivity and growth; 5-rationing in credit markets; 6- repayment issues in agricultural credit;; 7- credit via micro finance institutions; 8- performance of agricultural credit pre and post reforms; 9- agricultural credit via Islamic Banking.

\section{Copyrights}

Copyright for this article is retained by the author(s), with first publication rights granted to the journal.

This is an open-access article distributed under the terms and conditions of the Creative Commons Attribution license (http://creativecommons.org/licenses/by/3.0/). 